\title{
Prospective sustainable production of safe food for growing population based on the soybean (Glycine max L. Merr.) crops under Cd soil contamination stress
}

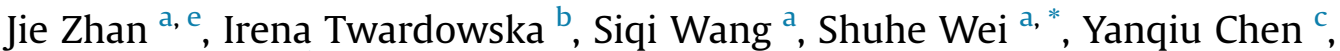 \\ Mihajlov Ljupco $^{\text {d }}$ \\ a Key Laboratory of Pollution Ecology and Environment Engineering, Institute of Applied Ecology, Chinese Academy of Sciences, Shenyang, 110016, PR China \\ ${ }^{\mathrm{b}}$ Institute of Environmental Engineering of the Polish Academy of Sciences, 41-819, Zabrze, Poland \\ c Crop Institute, Liaoning Academy of Agricultural Science, Shenyang, Liaoning, 110161, China \\ ${ }^{\mathrm{d}}$ Faculty of Agriculture, Goce Delcev Univeristy, Stip, 2000, Republic of Macedonia \\ e Liaoning Vocational College of Medicine, Shenyang, 110101, PR China
}

\section{A R T I C L E I N F O}

\section{Article history:}

Received 5 June 2018

Received in revised form

26 November 2018

Accepted 29 November 2018

Available online 3 December 2018

\section{Keywords:}

Cd polluted soil

Food safety/security

Cd low-accumulating soybean cultivars

$\mathrm{Cd}$ seed accumulation factors

Seed protection mechanisms

cd load balance

\begin{abstract}
A B S T R A C T
Sustainable food production for steadily growing world's population under the conditions of increasing environmental stress and soil pollution is a challenge that calls for optimization of farmland resource management. Soybean (Glycine max. L. Merr) as one of the world's most important protein crops can play a leading role in addressing global food security provided it fulfills safety requirements, in particular with respect to Cd level. The aim of this comparative study was elaborating efficient methods for the selection of soybean cultivars assuring safe $\mathrm{Cd}$ contents for food/feed purposes. The pot culture experiment was conducted using 15 soybean cultivars grown in soil moderately polluted with $\mathrm{Cd}\left(1.98 \mathrm{mg} \mathrm{kg}^{-1}\right)$, and in unpolluted soil $\left(0.15 \mathrm{mg} \mathrm{Cd} \mathrm{kg}^{-1}\right)$ as a control. The evaluation was based on the novel Cd concentration/ load trend analysis in plant tissues, Seed Accumulation Factors $\mathrm{SAF}_{n}$ and $\mathrm{Cd}$ load balance. The soybean demonstrated fundamentally different response of the same cultivars to low and moderate Cd concentrations in soil. In cultivars grown in unpolluted soil, besides genetically determined detoxification factors, important seed protective role played $\mathrm{Cd}$ accumulation in stem, leaves and root (Seed Accumulation Factor $\mathrm{SAF}_{n}<0.5, \mathrm{Cd}$ load reduction in bean by $25-82 \%$ ). In the moderately polluted soil, the most essential effect on $\mathrm{Cd}$ accumulation in seed exerted a plant genotype determining Cd flux and translocation from soil to shoot via root (Enrichment Factor $\mathrm{EF}<1$ ), while seed protection by accumulating $\mathrm{Cd}$ in other plant tissues was weak, declining or none $\left(\mathrm{SAF}_{n}>0.5\right.$ up to $>1$, whereas $\mathrm{Cd}$ load in bean ranged from -23 to $+11 \%$ related to mean value in shoot). Root to shoot flux rate was found to be a decisive factor in $\mathrm{Cd}$ enrichment in soybean seed at the elevated soil pollution with $\mathrm{Cd}$. The efficient screening for safe $\mathrm{Cd}$ content in soybean should be thus based on EF and Cd concentrations in shoot at the actual target soil pollution level.
\end{abstract}

(C) 2018 Elsevier Ltd. All rights reserved.

\section{Introduction}

Among world crops, soybean (Glycine max L. Merr.) holds an outstanding position in addressing global food security by 2050 as one of the world's most important protein sources (Borgenproject, 2014; Philis et al., 2018). It has a leading share (>50\%) in global oilseed output and accounts for over $60 \%$ of world meal production

\footnotetext{
* Corresponding author.

E-mail address: shuhewei@iae.ac.cn (S. Wei).
}

(Thoenes, 2005), being the major protein supply in animal feed (FAO, 2018). Currently, soybean cultivation is highly concentrated geographically. Four countries - USA, Brazil, Argentina and China produce almost $90 \%$ of world output that reached $336.62 \mathrm{Mt}$ in 2017 (STATISTA, 2018). To meet increasing food demand for world's growing population under climate change condition, its import and production steadily increase (Global Soybean Production, 2017). Considering generally high temperature and drought tolerance of soybean cultivars (Araji et al., 2018) that can be further enhanced genetically/genomically (Raza et al., 2016), and paramount properties of soybean as an ample source of protein for food and feed, its 
growing share in consumption pattern can ensure sustainable future food supply based on the existing farmland areas, and thus proper environmental management and protection of other ecosystems. However, consumption sustainability requirements comprise not only quantitative, but also qualitative parameters and an assurance of qualitative food/feed safety, in particular of safe concentrations of Potentially Toxic Elements (PTEs) in crop edible parts.

One of the most problematic PTEs worldwide is cadmium, a non-essential metal that has been recognized as one of the most widespread soil pollutants and ecotoxic elements posing severe adverse effect on all biological processes. Its natural content in the Earth crust accounts for $0.1 \mathrm{mg} \mathrm{kg}^{-1}$, while the world average in uncontaminated soil is estimated as $0.41 \mathrm{mg} \mathrm{kg}^{-1}\left(0.2-1.1 \mathrm{mg} \mathrm{kg}^{-1}\right.$ in different regions). Maximum Allowable Concentrations (MAC) in soil range from 1 to $5 \mathrm{mg} \mathrm{Cd} \mathrm{kg}^{-1}$, while Trigger Action Values (TAV) cover the range $2-20 \mathrm{mg} \mathrm{Cd} \mathrm{kg}^{-1}$ (Kabata-Pendias, 2011).

The problem with $\mathrm{Cd}$ pollution control lays, on the one hand, in the variety of emission sources, and on the other hand, in its airborne properties. It is targeted by the United Nations Economic Commission for Europe (UNECE) Convention on Long-range Transboundary Air Pollution (CRLTAP, 1983), which now has 51 parties in America and Eurasia, and by the Co-operative Programme for Monitoring and Evaluation of Long-range Transmission of Air Pollutants in Europe (EMEP, 1984) as one of the three priority metal pollutants (along with $\mathrm{Pb}$ and $\mathrm{Hg}$ ). Annual EMEP reports and soil data (EMEP Status Report 2, 2017) show commonly occurring Cd pollution of croplands caused by anthropogenic emissions, secondary re-suspension from natural sources and historical deposition, and from non-EMEP transboundary transport. Annual mean $\mathrm{Cd}$ concentrations in the air over the EMEP region lie within $0.1-1 \mathrm{ng} \mathrm{m}^{-3}$ and the highest deposition fluxes to croplands are within $30-150 \mathrm{~g} \mathrm{~km}^{-2} \mathrm{y}^{-1}$. The maximum Cd spatial distribution probability density over the EMEP domains is at $10-20 \mathrm{~g} \mathrm{~km}^{-2} \mathrm{y}^{-1}$ slowly decreasing over about three decades by up to $60 \mathrm{~g} \mathrm{~km}^{-2} \mathrm{y}^{-1}$ (EMEP Status Report 2, 2017).

Airborne $\mathrm{Cd}$ emission sources include variety of combustion processes, chemical and construction industries, and other anthropogenic activities that largely contribute to $\mathrm{Cd}$ deposition and accumulation in soil. Also, applications of sewage sludge, some pesticides and phosphorous fertilizers to cropland take part in its contamination. This makes $\mathrm{Cd}$ a widespread historical cropland soil pollutant, mostly at the moderate level $\left(>1-3 \mathrm{mg} \mathrm{kg}^{-1}\right)$, within MAC range. In China, the geological background level of $\mathrm{Cd}$ is low (mean $0.097 \mathrm{mg} \mathrm{kg}^{-1}$ ), however industrial emissions, wastewater irrigation and solid waste disposal result in soil pollution that reach 3-5 mg Cd kg-1 (Cheng, 2003), including agricultural soils in Southern China (Zhao et al., 2014) and the Yangtze River region (Liu et al., 2016). Actually, more than $20 \%$ of arable land (about $2 \cdot 10^{7}$ ha) is polluted with trace metals, including Cd (after He et al., 2015).

International allowable limit of $\mathrm{Cd}$ proposed by the Codex Alimentarius Commission (2001) for soybean accounts for $0.20 \mathrm{mg} \mathrm{kg}^{-1}$ that complies with Maximum Level of Contaminants in Foods (MLs) according to the National Food Quality Standard of China GB 2762-2012 (MHC, 2013). The Tolerance Limit of Heavy Metals for Feed established Cd concentration in animal feed for $0.5 \mathrm{mg} \mathrm{kg}^{-1}$ (CECSPC, 2009).

The existing data show that soybean is highly susceptible to $\mathrm{Cd}$ pollution. While reports on Cd contents in soybean seeds in the USA and Brasil that are the major global producers of soybean $-34.8 \%$ and $30.9 \%$ of total (Global Soybean Production, 2017) show low mean concentrations $\left(0.064 \mathrm{mg} \mathrm{kg}^{-1}\right.$ and $0.023-0.106 \mathrm{mg} \mathrm{kg}^{-1}$, respectively), they are all attributed to unpolluted soils with low mean natural Cd content, $0.33 \mathrm{mg} \mathrm{kg}^{-1}$ in the USA (Page et al., 1987) and $0.11 \mathrm{mg} \mathrm{kg}^{-1}$ in Brasil (Corguinha et al., 2015). However, soybean appears to contain the highest mean and maximum concentrations of Cd among seed crops and grains (wheat, rice, field and sweet corn, peanuts, soybean), and exceeds allowable levels at higher natural Cd contents in soil (Page et al., 1987). Reports from other countries confirm soybean excessive Cd uptake, the highest among 24 common food crops in Nigeria, and elevated accumulation even from soils of low Cd content (Orisakwe et al., 2012). A large-scale 2002 survey in Japan showed that $16.7 \%$ of soybean seeds exceeded the limit of $0.2 \mathrm{mg} \mathrm{kg}^{-1}$, in much higher proportion than other upland crops (Kobori et al., 2011). Also, any anthropogenic contamination with Cd, e.g. by pig manure application (Xu et al., 2015) or due to industrial emissions (Zhuang et al., 2013) even within quality standards for agricultural soils, resulted in its enrichment in soybean exceeding the allowable limits, as show reports from different regions of the world, e.g. from Argentina (Salazar et al., 2012) or China (Zhao et al., 2014). This indicates the general weak protective mechanisms in soybean cultivars against Cd accumulation in beans.

For this reason, a secure $\mathrm{Cd}$ level in soybean is of particular importance. Simultaneously, despite a great variety of soybean cultivars, the research on assuring secure $\mathrm{Cd}$ concentrations in soybean seeds is surprisingly scarce. All reported experiments were concentration-based only and conducted on the limited range of $\mathrm{Cd}$ concentrations in soil and soybean genotypes. While the differences in Cd uptake and accumulation depending on Cd concentration (Ishikawa et al., 2005)) and some chemical parameters of soil, such as pH, cations and organic acid (Zhou et al., 2016), and between different soybean genotypes were commonly noticed (Arao et al., 2003) and confirmed (Kobori et al., 2011); some researchers suggested accumulation in roots (Sugiyama et al., 2007) or in leaves (Sugiyama, 2009) as a mechanism that prevents Cd accumulation in seeds. Attempts to identify genetic control of $\mathrm{Cd}$ accumulation in soybean seeds by one major QTL $(c d 1)$ on Chromosome 9 (Benitez et al., 2010) or by the utilization of Cda1 locus and the determination of the function of GmHMA1 (Jegadeesan et al., 2016), and to select cadmium excluding soybean cultivars (Zhi et al., 2015), were also undertaken. However, results of these studies cannot be considered satisfactory due to the limited scale and casualness in the research design, entirely concentration-based conclusions, and in particular the lack of systematized data processing such as trend analysis and accumulated load balance. This severely hampers interpretation, as not concentrations, but loads are a real measure of contaminant accumulation and redistribution in a plant, and of a protective function of specific parts of the plant. In view of widespread elevated Cd content in agricultural soils and susceptibility of soybean to $\mathrm{Cd}$ accumulation, assuring a secure $\mathrm{Cd}$ level in soybean seeds is crucial for the future sustainable development (green/sustainable food supply) under climate change conditions and soybean-based sustainable consumption.

This comparative study was aimed at the elaboration of efficient methods for selecting Cd low-accumulation soybean cultivars, exemplified in a study on 15 cultivars grown in northeast China of temperate climate with the average annual temperature, precipitation and frostless period about $5-9{ }^{\circ} \mathrm{C}, 650-700 \mathrm{~mm}$ and 127-164 days, respectively (Zhan et al., 2013).

We hypothesized that seeds (bean) of some soybean cultivars could show low $\mathrm{Cd}$ accumulation properties. Based on the newly developed and applied Cd concentration/load trend analysis, Seed Accumulation Factors $\mathrm{SAF}_{\mathrm{n}}$, i.e. $\mathrm{C}_{\text {seed }} / \mathrm{C}_{n}$ - partial Seed Accumulation Factor $n$ (ratio of mean Cd concentration in seed to that in a part $n$ of a plant: root $\left(\mathrm{SAF}_{\mathrm{Rt}}\right)$, stem $\left(\mathrm{SAF}_{\mathrm{St}}\right)$, leaf $\left(\mathrm{SAF}_{\mathrm{Lf}}\right)$ and pod $\left(S A F_{P d}\right)$, was as indicators of seed protection level, and $\mathrm{Cd}$ load balance in different parts of plants grown in moderately polluted and unpolluted soils, concentration- and load-based Cd translocation and accumulation characteristics of soybean were assessed in relation to Cd enrichment in seeds and other parts of the plant, 
protection mechanisms were identified, and their actual role and variability evaluated quantitatively, as a share of surplus or deficit loads with respect to mean values.

The reliability and comparability of data were enhanced by using in the experiments the same non-spiked soil from two locations, uncontaminated and moderately polluted with $\mathrm{Cd}$ from the historical use of industrial wastewater for irrigation.

\section{Materials and methods}

\subsection{Basic properties of soil samples}

Soil sample containing $1.98 \mathrm{mg} \mathrm{Cd} \mathrm{kg}^{-1}$ was collected from the top layer $(0-20 \mathrm{~cm})$ of a farmland irrigated with wastewater in the suburb of Shenyang city, northeast China $\left(41^{\circ} 74^{\prime} 267 \mathrm{~N}\right.$ and $123^{\circ} 21^{\prime} 666$ E). According to the Soil-Environmental Quality Standards of China (MEP, 2007) this field was classified as moderately contaminated with $\mathrm{Cd}$. In turn, this contamination level falls within the range of Maximum Allowable Concentrations MAC (1-5 mg Cd $\mathrm{kg}^{-1}$ ) compiled from various sources (Kabata-Pendias, 2011).

As a control (CK), unpolluted soil with background concentration of $0.15 \mathrm{mg} \mathrm{Cd} \mathrm{kg} \mathrm{g}^{-1}$ was sampled from the same meadow burozem soil type at the Shenyang Station of Experimental Ecology of the Chinese Academy of Sciences (CAS) $\left(41^{\circ} 72^{\prime} 728 \mathrm{~N}\right.$ and $123^{\circ} 20^{\prime} 212 \mathrm{E}$ ). The unpolluted soil sample were with $\mathrm{pH} 6.8$, CEC $22.9 \mathrm{cmol} \mathrm{kg}^{-1}$, Clay $22.1 \%$, Silt $43.4 \%$, Sand $34.5 \%$, TOC $15.20 \mathrm{~g} \mathrm{~kg}^{-1}$, Total-N $1.89 \mathrm{~g} \mathrm{~kg}^{-1}$, Available-P $12.46 \mathrm{mg} \mathrm{kg}^{-1}$, Available-K $181.02 \mathrm{mg} \mathrm{kg}^{-1}$, Total-Cd $0.15 \mathrm{mg} \mathrm{kg}^{-1}$, Total-As $9.84 \mathrm{mg} \mathrm{kg}^{-1}$, Total-Cu $24.68 \mathrm{mg} \mathrm{kg}^{-1}$, Total-Cr $52.38 \mathrm{mg} \mathrm{kg}^{-1}$, Total-Hg $0.06 \mathrm{mg} \mathrm{kg}^{-1}$, Total-Ni $29.14 \mathrm{mg} \mathrm{kg}^{-1}$, Total-Pb $25.16 \mathrm{mg} \mathrm{kg}^{-1}$ and Total-Zn $51.28 \mathrm{mg} \mathrm{kg}^{-1}$. The selection of soil samples was based on a similarity of soil type and of all its basic parameters, to avoid possible substantial influence of any parameter other than $\mathrm{Cd}$ concentration. Total $\mathrm{Cd}$ in polluted soil sample was $1.98 \mathrm{mg} \mathrm{kg}^{-1}$. The basic physicochemical characteristics such as $\mathrm{pH}$ (6.7), CEC $\left(23.7 \mathrm{cmol} \mathrm{kg}^{-1}\right)$, and so on same as the unpolluted soil (CK). The total concentrations of $\mathrm{Cu}, \mathrm{Pb}, \mathrm{Ni}, \mathrm{Zn}, \mathrm{Cr}, \mathrm{Hg}$ and $\mathrm{As}$ in uncontaminated and contaminated soils are similar, and are considerably below ( $\mathrm{As}, \mathrm{Cu}, \mathrm{Hg}, \mathrm{Zn}$ ) or at the lowest level $(\mathrm{Cr}, \mathrm{Ni}, \mathrm{Pb})$ of Maximum Allowable Concentrations (MAC) in soil (Kabata-Pendias, 2011). They do not exceed the Soil-Environmental Quality Standards of China (MEP, 2007).

\subsection{Pot culture experiment}

Seeds of 15 different soybean cultivars brought to market in 1996-2011 and commonly grown in China, mostly in Northeast and Northwest provinces, were obtained from Doufeng Company at Shenyang. Soybean cultivars studied in pot culture experiment was numbered with D1 (Liaodou 11), D2 (Liaodou 15), D3 (Liaodou 17), D4 (Liaodou 18), D5 (Liaodou 19), D6 (Liaodou 21), D7 (Liaodou 24), D8 (Liaodou 29), D9 (Liaodou 30), D10 (Liaodou 31), D11 (Liaodou 33), D12 (Tiefeng 31), D13 (Liaohedou2), D14 (Liao00136) and D15 (Fuxian3).

All Liaodou cultivars $(11,15,17,18,19,21,24,29,30,31,33)$ and Liaoheidou 2 were reared by Liaoning AAS (Academy of Agricultural Sciences), Tiefeng 31 by Tieling AAS and Fuxian 3 by Fushun AAS. Two of these cultivars, Liaodou 21 (D6) and Tiefeng 31 (D12) were tested previously for Cd uptake from two industrially contaminated soils with $\mathrm{Cd}$ content up to $1.25 \mathrm{mg} \mathrm{kg}^{-1}$, and Tiefeng 31 was defined as a good candidate for a Cd-excluding cultivar (Zhi et al., 2015).

For the tested cultivars, the overall growth temperature is $15-25^{\circ} \mathrm{C}$ (average $20^{\circ} \mathrm{C}$ ), while the growth duration ranges from 109 to 135 days (Wang and Song, 2008), hence the experimental growing conditions were maintained at a similar level. The pot culture experiment was conducted at a temperature-controlled glasshouse $\left(20 \pm 5^{\circ} \mathrm{C}\right)$ of the Institute of Applied Ecology of CAS, Shenyang, China. Portions of thoroughly homogenized soil samples $(2.5 \mathrm{~kg}, \mathrm{dw}$ - dry weght) were filled into plastic pots $(\phi=20 \mathrm{~cm}$, $\mathrm{H}=18 \mathrm{~cm}$ ).

At springtime, six soybean seeds of each cultivar per pot, after prior sterilization for $10 \mathrm{~min}$ in $2 \%(\mathrm{~V} / \mathrm{V}) \mathrm{H}_{2} \mathrm{O}_{2}$, were sown in triplicate to randomly placed pots with unpolluted $\left(0.15 \mathrm{mg} \mathrm{Cd} \mathrm{kg}{ }^{-1}\right)$ and moderately contaminated $\left(1.98 \mathrm{mg} \mathrm{Cd} \mathrm{kg}^{-1}\right)$ soil. Losses of water were replenished to maintain $80 \%$ of soil water-holding capacity that is usually practiced in the local soybean production.

Two weeks after germination, when the seedlings of soybean were about $5 \mathrm{~cm}$ high, 3 uniform seedlings with two leaves in each pot were selected for growth. After reaching maturity about 120 days after germination, all tested soybean plants were harvested.

\subsection{Sample analysis and data processing}

Collected plant samples were rinsed with tap water and next carefully washed with deionized water. The plants were separated into root, stem, leaf, pod and seed (bean), oven-dried at $105^{\circ} \mathrm{C}$ for $5 \mathrm{~min}$, and at $70^{\circ} \mathrm{C}$ for about 2 days until reaching constant dry weight. The dried plant samples were then weighed to assess biomass, powdered and passed through a $0.3 \mathrm{~mm}$ sieve to obtain a uniform analytical material.

Dried soil and plant samples were digested using concentrated nitric acid and perchlorate $\left(87 \% \mathrm{HNO}_{3} / 13 \% \mathrm{HClO}_{4}\right)$ for the determination of total Cd concentrations (Lu, 1999). The obtained solutions were analyzed for $\mathrm{Cd}$ by atomic absorption spectrophotometry (AAS, WFX-120A with $1.3 \mathrm{~nm}$ spectral bandwidth). For Quality Assurance/Quality Control, certified standard reference material (NIST SRM 1547, peach leaves) was used.

Basic soil properties ( $\mathrm{pH}$, cation exchange capacity (CEC), clay, silt and sand share, total organic carbon (TOC), total N, available P and $\mathrm{K}$ ) were determined by routine soil analysis and using relevant ISO standards on soil quality (Jones Jr., 2001).

Microsoft EXCEL was used for data processing and calculations of standard errors. All treatment responses were analyzed by oneway analysis of variance and Least Significant Difference method multiple range tests to separate means using the SPSS software. Differences were considered significant at the $p<0.05$ level. Significance of differences at the $\mathrm{p}<0.01$ level was also provided.

\subsection{Criteria used for selection of Cd low-accumulating cultivars (Cd-excluders)}

The major criterion used for selecting Cd low-accumulating cultivars (Cd-excluders) was their fulfilling international (Codex Alimentarius Commission, 2001) and national food safety standards for Cd concentration in edible parts of cultivars (seeds) grown in polluted soil (MHC, 2013).

In this study, we focused in more details on processes of $\mathrm{Cd}$ uptake from soil and pathways of its translocation, redistribution and accumulation in different parts of a plant, with particular regard to the possible seed protection mechanisms against $\mathrm{Cd}$ accumulation. The study was conducted as a comparative one, by evaluating $\mathrm{Cd}$ concentrations $\mathrm{C}_{n}$, biomass $\mathrm{B}_{n}$ and accumulated $\mathrm{Cd}$ loads $\mathrm{L}_{n}$ in root, shoot, stem, leaf, pod and seed tissues (marked as $n$ indices) of studied different soybean cultivars grown in moderately

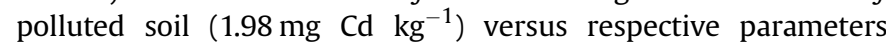
assessed for the same cultivars grown in unpolluted soil $(0.15 \mathrm{mg}$ $\mathrm{Cd} \mathrm{kg}^{-1}$ ), their response to pollution and an effect on seed safety as a foodstuff.

For this purpose, enrichment (EF) and translocation (TF) factors 
for different cultivars were assessed (Liu et al., 2010). The potential of a plant to uptake and accumulate $\mathrm{Cd}$ from soil was expressed as an enrichment factor $\left(\mathrm{EF}=\mathrm{C}_{\text {shoot }} / \mathrm{C}_{\text {soil }}\right)$. For a metal excluder, $\mathrm{EF}$ should be $<1$. Translocation factor $\left(\mathrm{TF}=\mathrm{C}_{\text {shoot }} / \mathrm{C}_{\text {root }}\right)$ characterizes the capacity of a plant to transfer elements from root to shoot; $\mathrm{TF}<1$ is a feature of low-accumulating crops (Liu et al., 2010).

To characterize accumulation of $\mathrm{Cd}$ in seeds and possible occurrence of seed protection mechanisms, we introduced a novel relative Seed Accumulation Factor $\mathrm{SAF}_{n}$; $\mathrm{SAF}_{\mathrm{Sh}}$ was estimated as a ratio of mean $\mathrm{Cd}$ concentration in seeds (beans) to that in shoot $\mathrm{SAF}_{\mathrm{Sh}}=\mathrm{C}_{\text {seed }} / \mathrm{C}_{\text {shoot }} ; \mathrm{SAF}_{\mathrm{Sh}}<1$ means that accumulation of $\mathrm{Cd}$ in beans is lower than in other parts of shoot, which indicates prevalence of a protective mechanism against $\mathrm{Cd}$ accumulation in seeds. The lower is $\mathrm{SAF}_{\mathrm{Sh}}$, the higher is seed protection. $\mathrm{SAF}_{\mathrm{Sh}}<0.5$ indicates high seed protection level. $\mathrm{SAF}_{\mathrm{Sh}} \approx 1$ shows that there is no specific protection against $\mathrm{Cd}$ accumulation in seeds, and $\mathrm{Cd}$ is evenly distributed within the aboveground parts of a cultivar. $S_{A F}$ $>1$ indicates that seeds are particularly susceptible to $\mathrm{Cd}$ accumulation, and $\mathrm{Cd}$ enrichment in seeds exceeds the average concentration in above-ground parts of a cultivar.

To assess relation of $\mathrm{Cd}$ concentrations in soil to that in seeds, and distribution of $\mathrm{Cd}$ concentrations in different parts of a cultivar related to that in seeds as an indicator of possible contribution of accumulation in some tissues to seed protection, partial Seed Accumulation Factors $\mathrm{SAF}_{n} v s$. concentrations in soil $\left(\mathrm{SAF}_{\text {Soil }}=\mathrm{C}_{\text {seed }} /\right.$ $\left.C_{\text {Soil }}\right)$, roots $\left(\mathrm{SAF}_{\mathrm{Rt}}=\mathrm{C}_{\text {seed }} / \mathrm{C}_{\mathrm{Rt}}\right)$, stem $\left(\mathrm{SAF}_{\mathrm{St}}=\mathrm{C}_{\text {seed }} / \mathrm{C}_{\mathrm{St}}\right)$, leaves $\left(\mathrm{SAF}_{\mathrm{Lf}}=\mathrm{C}_{\text {seed }} / \mathrm{C}_{\mathrm{Lf}}\right)$ and pod $\left(\mathrm{SAF}_{\mathrm{Pd}}=\mathrm{C}_{\text {seed }} / \mathrm{C}_{\mathrm{Pd}}\right)$ were also evaluated. Similarly, the lower is $\mathrm{SAF}_{n}$, the better is seed protected, and the higher is contribution of a part $n$ to seed protection against $\mathrm{Cd}$ enrichment.

Since the distribution of a contaminant within a plant is characterized not by its concentration, but by the total load of a contaminant accumulated in the each part of a plant $\mathrm{L}_{n}$, the relevant Cd loads in seed, root, stem, leaf were assessed as $\mathrm{L}_{n}=\mathrm{C}_{n} \mathrm{~B}_{n}(\mu \mathrm{g}$ pot $^{-1}$ ), where $C$ means $C d$ concentration, $B$ is a biomass, and index $n$ means the particular part of the plant. The $\mathrm{Cd}$ enrichment or depletion in particular tissues of a shoot with respect to total load in shoot allowed for evaluating the actual contaminant redistribution within the plant and the possible role of particular parts of a plant in the seed protection.

\section{Results}

\subsection{Cd accumulation in seeds of soybean cultivars grown in moderately polluted and natural unpolluted soils}

A trend graph in a growing sequence (Fig. 1A), illustrates Cd accumulation in seeds (beans) of different soybean cultivars grown in the moderately polluted soil $\left(1.98 \mathrm{mg} \mathrm{Cd} \mathrm{kg}^{-1}\right)$. There was almost 6-fold difference between the lowest $\left(0.30 \mathrm{mg} \mathrm{Cd} \mathrm{kg}^{-1}\right.$ in D8 Liaodou 29) and the highest (1.77 $\mathrm{mg} \mathrm{Cd} \mathrm{kg}^{-1}$ in D13 - Liaoheidou 2) Cd concentration in beans of 15 cultivars, at the average Cd concentration for all investigated cultivars accounting for $0.74 \mathrm{mg} \mathrm{kg}^{-1}$. The $C_{\text {seed }}<0.5 \mathrm{mg} \mathrm{Cd} \mathrm{kg}^{-1}$, besides $\mathrm{D} 8$, were found in D3 $<$ D2 $<$ D15 $<$ D14 < D11.

The concentrations of $\mathrm{Cd}$ in shoot and its other parts (pod, leaf and stem) in general followed the same pattern (Fig. 1A). Cd concentrations in roots did not present the same trend as that in beans and above-ground parts of plants and showed high irregularity at considerably higher concentration range than in shoot, which indicates barrier role of roots to $\mathrm{Cd}$ translocation to shoot. The $\mathrm{Cd}$ concentration range and mean values in the tested shoot tissues represented the order: $C_{\text {leaf }}>C_{\text {stem }}>C_{\text {seed }}>C_{\text {pod }}$ (Fig. 1A).

The concentration pattern of $\mathrm{Cd}$ in the soybean cultivars grown in the unpolluted soil aligned in the order of increasing concentrations in beans of the same cultivars grown in the moderately polluted soil did not follow the same trend and presented random fluctuations ranging from $0.03 \mathrm{mg} \mathrm{Cd} \mathrm{kg}^{-1}$ (D11) to $0.15 \mathrm{mg} \mathrm{Cd} \mathrm{kg}^{-1}$ (D5) (Fig. 1B vs. Fig. 1A). The average $\mathrm{C}_{\text {seed }}=0.074 \mathrm{mg} \mathrm{Cd} \mathrm{kg}^{-1}$ was 10 -fold lower than in the moderately polluted soil.

Another considerable difference in $\mathrm{Cd}$ accumulation behavior was noticed in trend patterns of Cd concentrations in root, shoot and particular parts of plants. In cultivars growing in the unpolluted soil, in contrast to cultivars growing in the moderately polluted soil, shoot, leaves and stem followed the pattern of that in root; while bean (seeds) and pod displayed different and much lower $\mathrm{Cd}$ enrichment pattern (Fig. 1B vs. Fig. 1A). This pattern suggested free undisturbed $\mathrm{Cd}$ translocation from roots to the above-ground parts of the plants, and specific $\mathrm{Cd}$ accumulation/protection mechanisms occurring in pod and bean (seed).

\subsection{Effect of $\mathrm{Cd}$ uptake and translocation on its accumulation in beans}

Enrichment (EF) and translocation factors (TF) related to $\mathrm{Cd}$ transport from soil to plants confirmed specificity of Cd uptake/ translocation behavior of the same cultivars grown in the moderately polluted and unpolluted soil. For all investigated cultivars grown in the moderately polluted soil, both enrichment factors (EF 0.19-0.94) (Fig. 2a) and translocation factors (TF 0.17-0.70) (Fig. 2b) were below 1 indicating evident, though differentiated barrier properties of a root system. By contrast, EF and TF values of soybean cultivars growing in the unpolluted soil, were substantially higher than these for the same cultivars growing in the moderately polluted soil (EF 1.13-3.27, TF 0.49-0.87) (Fig. 2 c, d). Moreover, EF of all cultivars except D3 and D11 exceeded 1. This indicates the lack or weak barrier mechanisms in Cd translocation from soil via root to plants growing in the unpolluted soil and occurrence of such flux blockage by roots at higher Cd concentrations in soil, where all EF and TF values were considerably below 1 and followed thoroughly different patterns (Fig. 2a, b vs. Fig. 2c, d).

\subsection{Occurrence of protective mechanisms against $C d$ enrichment in seeds}

The lack of conformity between Cd accumulation in bean and shoot, and between EF and TF for the tested cultivars and the soil pollution level evidently results from divergent $\mathrm{Cd}$ enrichment of the different parts of shoot and diverse seed protection capacity of the tested cultivars indicated by a relative $\mathrm{Cd}$ accumulation factors in seeds $\mathrm{SAF}_{n}$ (Tables 1 and 2).

The actual seed protection capacity due to $\mathrm{Cd}$ redistribution in shoot, among all 15 tested cultivars grown in the moderately polluted soil, showed 7 cultivars: D2, D5, D14, D3, D12, D8, D15 $\left(\mathrm{SAF}_{\mathrm{Sh}}=0.71-0.82\right)$. However, $\mathrm{SAF}_{\mathrm{Sh}}$ values $>0.5$ indicate a rather weak seed protection level in all these cultivars compared to mean Cd enrichment in shoot.

Moreover, Cd accumulation in beans (seeds) of other cultivars was either about the same (D11, D4, D9, D1, D13)) $\left(\mathrm{SAF}_{\mathrm{Sh}} \approx 1.0\right)$, or was substantially higher than in shoot (D10, D6, D7) $\left(\mathrm{SAF}_{S h}>1\right)$.

Simultaneously, a relative $\mathrm{Cd}$ accumulation in seeds $\mathrm{SAF}_{\mathrm{Sh}}=\mathrm{C}_{\text {seed }} / \mathrm{C}_{\text {shoot }}=0.09-0.69$ (average 0.40 ) for all studied cultivars grown in the unpolluted soil was mostly $<0.5$, which indicated high protection capacity of seeds (Table 1). The lowest SAF value $\left(\mathrm{SAF}_{\mathrm{Sh}}=0.09\right)$ showed D12 cultivar (Tiefeng 31), the potential Cd-excluder, which exhibited also one of the lowest Cd concentration in beans $\left(0.04 \mathrm{mg} \mathrm{kg}^{-1}\right)$ of all cultivars growing in the unpolluted soil. The lowest concentration of $\mathrm{Cd}$ in beans $\left(0.03 \mathrm{mg} \mathrm{kg}^{-1}\right)$ was detected in cultivar D11 (Fig. 1B). To estimate 
A

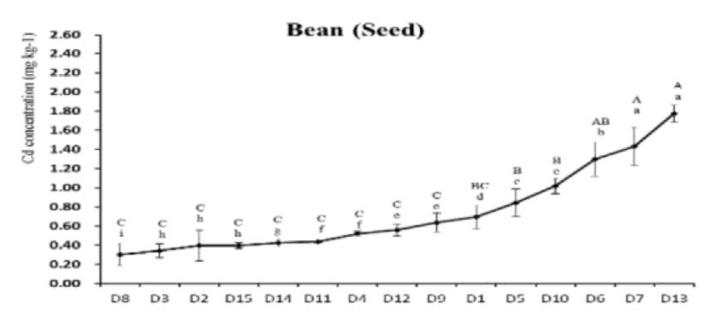

Pod
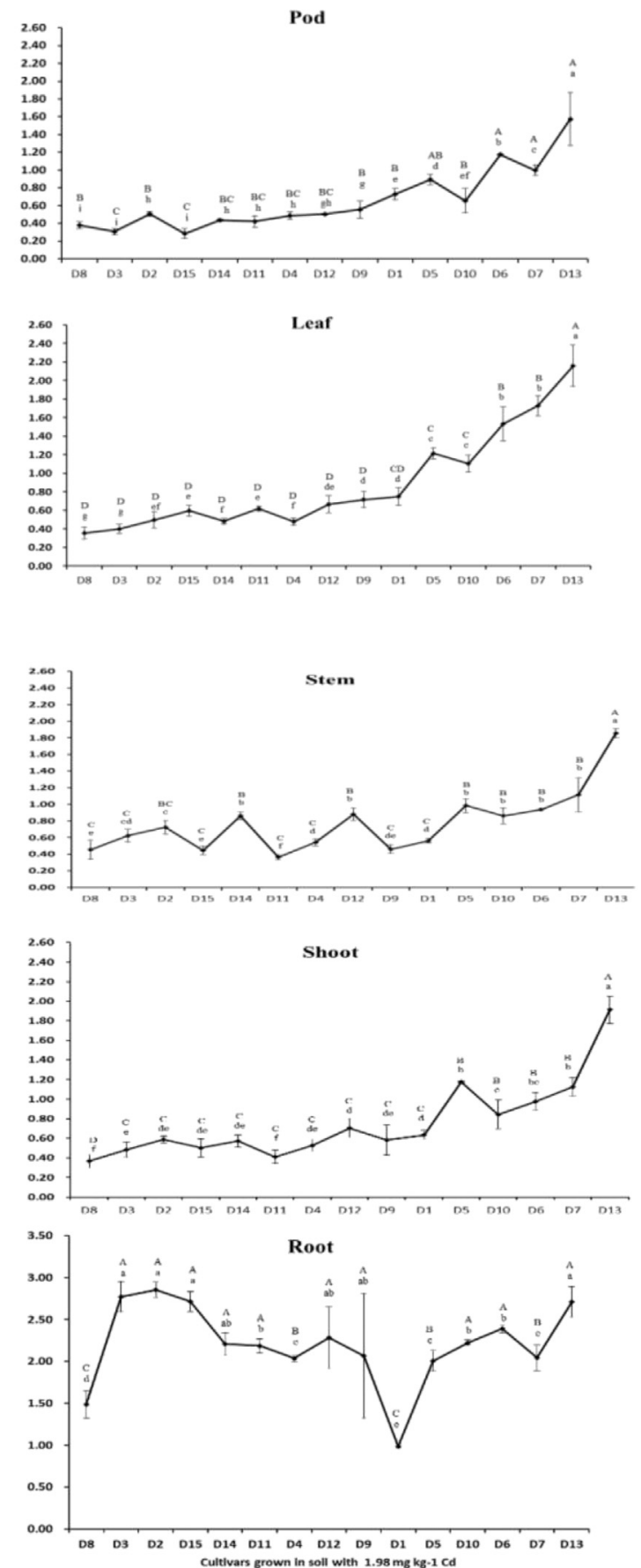

B
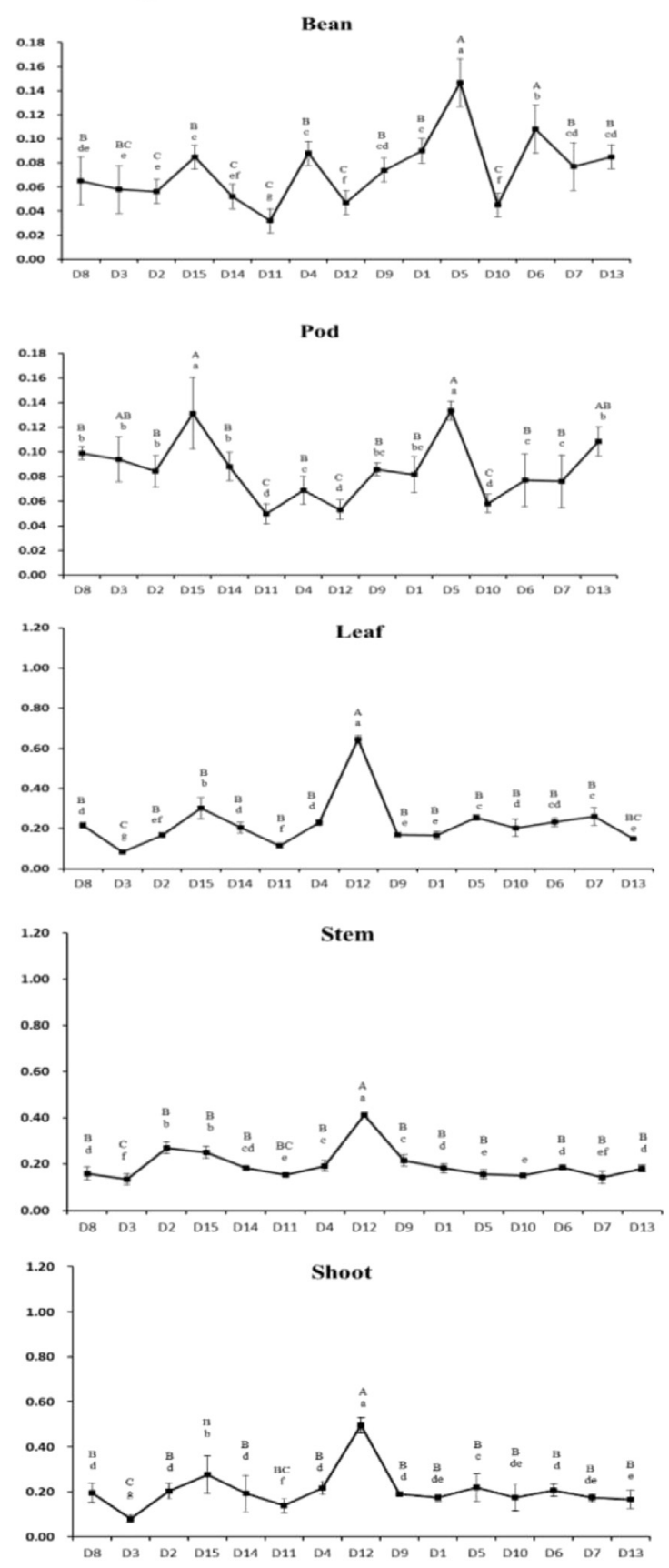

Root

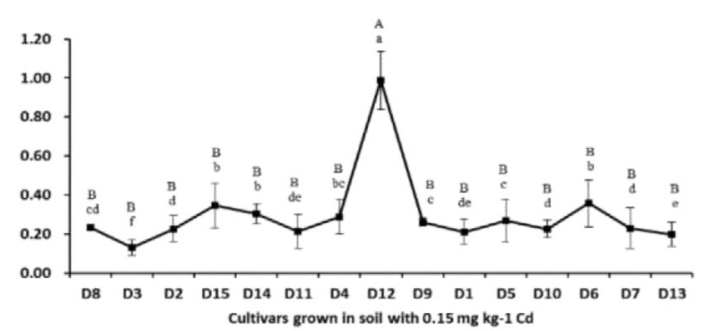

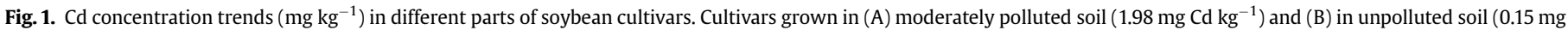
$\mathrm{Cd} \mathrm{kg}^{-1}$ ). Concentration values are aligned in the order of increasing concentrations in beans of cultivars growing in moderately polluted soil. Values are means \pm S.D. $(\mathrm{n}=3$ ). (Data marked by the same lowercase letters over points are not significantly different at $p<0.05$, and by the same capital letters - at $p<0.01$ ). 

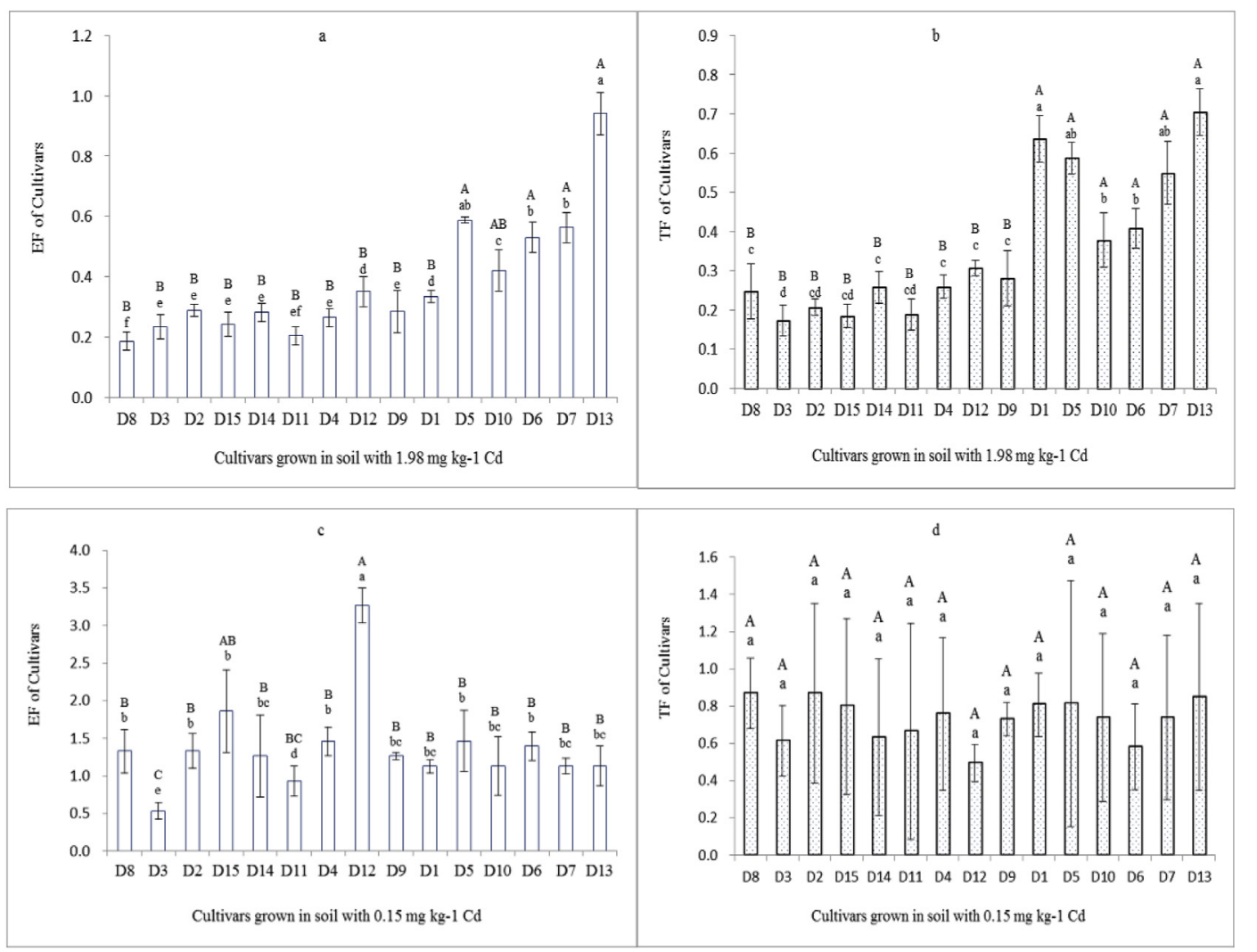

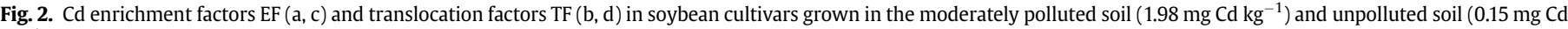
$\left.\mathrm{kg}^{-1}\right)$. Cultivars are aligned in the order of increasing Cd concentrations in beans.

(Data marked by the same lowercase letters over column bars are not significantly different at $p<0.05$, and by the same capital letters - at $p<0.01$ ).

Table 1

Seed protection capacity of soybean cultivars.

\begin{tabular}{|c|c|c|c|c|c|c|c|}
\hline \multirow[t]{2}{*}{ Cultivar $\left.^{*}\right)$} & \multirow[t]{2}{*}{ No. } & \multicolumn{3}{|c|}{$\mathrm{C}_{\text {soil }}=0.15 \mathrm{mg} \mathrm{kg}^{-1}$} & \multicolumn{3}{|c|}{$\mathrm{C}_{\text {soil }}=1.98 \mathrm{mg} \mathrm{kg}^{-1}$} \\
\hline & & $\mathrm{C}_{\text {shoot }}$ & $\mathrm{C}_{\text {seed }}$ & $\mathrm{SAF}_{\mathrm{Sh}}$ & $\mathrm{C}_{\text {shoot }}$ & $\mathrm{C}_{\text {seed }}$ & $\mathrm{SAF}_{\mathrm{Sh}}^{* *}$ \\
\hline Liaodou 29 & D8 & $0.20 \pm 0.04 \mathrm{cB}$ & $0.06 \pm 0.02 \mathrm{cdB}$ & $0.35 \pm 0.15 \mathrm{~dB}$ & $0.37 \pm 0.07 \mathrm{gCD}$ & $0.30 \pm 0.12 \mathrm{hC}$ & $0.80 \pm 0.21 \mathrm{bcB}$ \\
\hline Liaodou 17 & D3 & $0.08 \pm 0.02 \mathrm{fD}$ & $0.06 \pm 0.02 \mathrm{cdB}$ & $0.73 \pm 0.27 \mathrm{aA}$ & $0.48 \pm 0.08 \mathrm{fC}$ & $0.34 \pm 0.07 \mathrm{ghC}$ & $0.76 \pm 0.11 \mathrm{cB}$ \\
\hline Liaodou 15 & $\mathrm{D} 2$ & $0.20 \pm 0.03 \mathrm{cB}$ & $0.06 \pm 0.01 \mathrm{cdB}$ & $0.31 \pm 0.11 \mathrm{deB}$ & $0.59 \pm 0.03 \mathrm{eC}$ & $0.40 \pm 0.16 g C$ & $0.71 \pm 0.30 \mathrm{~dB}$ \\
\hline Fuxian 3 & D15 & $0.28 \pm 0.08 \mathrm{bB}$ & $0.08 \pm 0.01 \mathrm{bcB}$ & $0.32 \pm 0.14 \mathrm{deB}$ & $0.50 \pm 0.09 \mathrm{fC}$ & $0.40 \pm 0.03 g C$ & $0.82 \pm 0.19 b c B$ \\
\hline Liao00136 & D14 & $0.19 \pm 0.08 \mathrm{~cd}$ & $0.05 \pm 0.01 \mathrm{deBC}$ & $0.29 \pm 0.11 \mathrm{dBC}$ & $0.57 \pm 0.06 \mathrm{eC}$ & $0.42 \pm 0.04 \mathrm{gC}$ & $0.75 \pm 0.13 \mathrm{cB}$ \\
\hline Liaodou 33 & D11 & $0.14 \pm 0.03 \mathrm{eC}$ & $0.03 \pm 0.01 \mathrm{deC}$ & $0.23 \pm 0.05 \mathrm{eC}$ & $0.41 \pm 0.07 \mathrm{gC}$ & $0.44 \pm 0.01 \mathrm{gC}$ & $1.06 \pm 0.20 \mathrm{abA}$ \\
\hline Liaodou 18 & D4 & $0.22 \pm 0.03 \mathrm{cB}$ & $0.09 \pm 0.01 \mathrm{bcB}$ & $0.45 \pm 0.07 \mathrm{bcB}$ & $0.53 \pm 0.06 \mathrm{efC}$ & $0.53 \pm 0.02 \mathrm{fBC}$ & $1.05 \pm 0.07 a b A$ \\
\hline Tiefeng 31 & D12 & $0.49 \pm 0.03 \mathrm{aA}$ & $0.04 \pm 0.01 \mathrm{deC}$ & $0.09 \pm 0.02 \mathrm{fD}$ & $0.70 \pm 0.10 \mathrm{~dB}$ & $0.56 \pm 0.06 \mathrm{efB}$ & $0.79 \pm 0.08 \mathrm{bcB}$ \\
\hline Liaodou 30 & D9 & $0.19 \pm 0.01 \mathrm{cdB}$ & $0.07 \pm 0.01 \mathrm{cB}$ & $0.39 \pm 0.05 \mathrm{cB}$ & $0.58 \pm 0.16 \mathrm{eC}$ & $0.64 \pm 0.10 \mathrm{eB}$ & $1.17 \pm 0.46 \mathrm{abA}$ \\
\hline Liaodou 11 & D1 & $0.17 \pm 0.01 \mathrm{dBC}$ & $0.09 \pm 0.01 \mathrm{bcB}$ & $0.52 \pm 0.09 \mathrm{bA}$ & $0.63 \pm 0.05 \mathrm{deC}$ & $0.70 \pm 0.12 \mathrm{eB}$ & $\overline{1.10 \pm 0.22} a b A$ \\
\hline Liaodou 19 & D5 & $0.22 \pm 0.06 \mathrm{cB}$ & $0.15 \pm 0.02 \mathrm{aA}$ & $0.69 \pm 0.16 \mathrm{aA}$ & $1.18 \pm 0.01 b B$ & $0.84 \pm 0.14 \mathrm{~dB}$ & $0.72 \pm 0.13 \mathrm{~dB}$ \\
\hline Liaodou 31 & D10 & $0.18 \pm 0.06 \mathrm{~dB}$ & $0.05 \pm 0.01 \mathrm{deBC}$ & $0.26 \pm 0.11 \mathrm{dC}$ & $0.84 \pm 0.15 \mathrm{cB}$ & $1.02 \pm 0.08 \mathrm{cAB}$ & $1.22 \pm 0.15 a A$ \\
\hline Liaodou 21 & D6 & $0.21 \pm 0.03 \mathrm{cB}$ & $0.11 \pm 0.02 \mathrm{bAB}$ & $0.52 \pm 0.15 b A$ & $0.98 \pm 0.09 b c B$ & $1.30 \pm 0.18 \mathrm{bA}$ & $\overline{1.35 \pm 0.29} \mathrm{aA}$ \\
\hline Liaodou 24 & D7 & $0.17 \pm 0.02 \mathrm{dBC}$ & $0.07 \pm 0.02 \mathrm{cB}$ & $0.45 \pm 0.11 b c A B$ & $1.12 \pm 0.10 \mathrm{bB}$ & $1.44 \pm 0.20 \mathrm{bA}$ & $1.28 \pm 0.09 \mathrm{aA}$ \\
\hline Liaoheidou 2 & D13 & $0.17 \pm 0.04 \mathrm{dBC}$ & $0.08 \pm 0.01 \mathrm{bcB}$ & $0.54 \pm 0.20 \mathrm{bA}$ & $1.91 \pm 0.14 \mathrm{aA}$ & $1.77 \pm 0.09 \mathrm{aA}$ & $\overline{0.93 \pm 0.11} \mathrm{bAB}$ \\
\hline
\end{tabular}

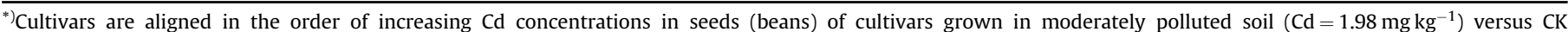
$\left(\mathrm{Cd}=0.15 \mathrm{mg} \mathrm{kg}^{-1}\right)$.

${ }^{* *} \mathrm{SAF}_{\mathrm{Sh}}=\mathrm{C}_{\text {seed }} / \mathrm{C}_{\text {shoot }}$ - mean $\mathrm{Cd}$ enrichment values in seeds (bean) related to mean overall concentrations in shoots.

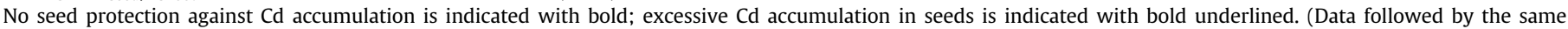
lowercase letters in the same column are not significantly different at $p<0.05$, and by the same capital letters - at $p<0.01$ ).

what mechanisms might possibly contribute to seed protection, partial seed accumulation factors related to soil, root and parts of shoot (stem, leaf and pod) were evaluated (Table 2).

The results show that there is no single prevailing protection factor against $\mathrm{Cd}$ accumulation in seed (bean). External protection of seeds through Cd accumulation in other parts of the plants grown in the moderately polluted soil occurred in root, stem and leaf, however to the different extent. In D8, D3, D2, D14, D12, D5 all three factors took part in the protective Cd accumulation. In D15, D11, D9, D6, D7 and D13, only root and leaf played protective role, while in D4, D1 and D10, the only protection factor was root. While $\mathrm{SAF}_{\mathrm{Rt}}$ and $\mathrm{SAF}_{\mathrm{St}}$ varied in a broad range, $\mathrm{SAF}_{\mathrm{Lf}}$ was relatively stable, however at the high mean level 0.81 indicating low protection capacity. 


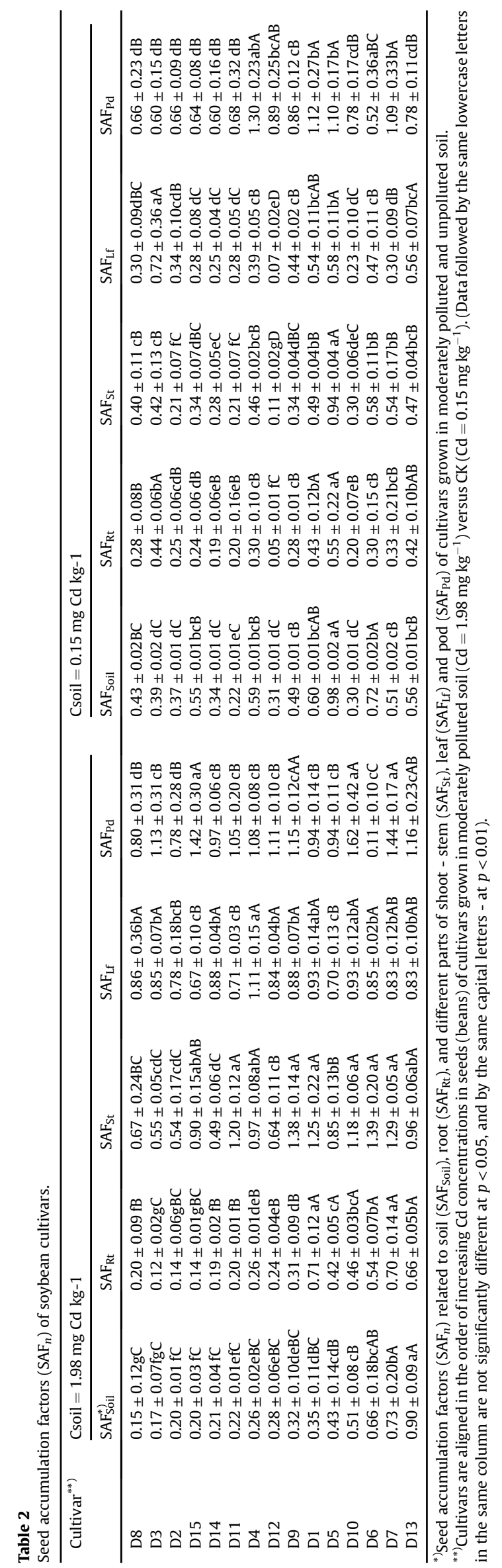

For cultivars grown in the unpolluted soil, all three factors contributed to seed protection, while $\mathrm{SAF}_{n}$ values, although also variable, were at the considerably lower level indicative for a high seed protection capacity.

\subsection{Biomass yield}

Biomass yield, on the one hand, is an indicator of the pollution impact on a cultivar growth. On the other hand, this is a decisive factor in the actual pollution load accumulation and distribution among the different parts of a plant.

The biomass yield of all cultivars (except considerably lesser biomass of D1 and D8) and its distribution between plant parts (root « shoot [seed $>$ stem>pod $>$ leaf]) showed high similarity and uniformity within the same soil pollution level (Tables 3 and 4; Fig. 3). Moderate pollution of soil with Cd $\left(1.98 \mathrm{mg} \mathrm{kg}^{-1}\right)$ resulted in the reduction of the biomass yield compared to the unpolluted soil, which followed a general decreasing sequence: root $>$ shoot [pod $>$ leaf $>$ stem $>$ bean (seed)] (Table 5).

Percentage range of biomass reduction was relatively low except D1 and D8 cultivars that appeared to be particularly sensitive to soil pollution with $\mathrm{Cd}$. Remarkable, that soybean cultivars did not show any relations between $\mathrm{Cd}$ concentration in seed (bean) (Fig. 1A) and biomass reduction in a plant and in any its part that varied in the narrow range (Table 5, Fig. 4/I). High stability and uniformity of biomass distribution between particular parts of a plant in all cultivars grown in the unpolluted and moderately polluted soil is illustrated with the lack of a significant difference of the biomasses share for both cases (Fig. 4/II).

\subsection{Distribution of Cd loads in soybean plants}

Due to the high similarity of a biomass yield in the majority of tested cultivars and uniformity of biomass distribution between different parts of plants, Cd load trends practically mimicked $\mathrm{Cd}$ concentration pattern (Fig. 5 vs. Fig. 1), however at fundamentally different value interrelations.

The highest Cd load was concentrated in shoot, in particular in seeds/pod, and the lowest in root (Fig. 6).

To evaluate the actual possible protective role of stem, leaf and pod against $\mathrm{Cd}$ accumulation in seeds (beans), redistribution of $\mathrm{Cd}$ loads between the shoot parts with respect to total load and mean concentration of $\mathrm{Cd}$ in shoot was assessed as the difference between actual Cd loads in specific parts of shoot (stem, leaf, pod and seed) and mean loads calculated on the basis of averaged Cd concentration in shoot and an actual biomass of a particular part of shoot. Surplus actual Cd loads with respect to mean values indicated $\mathrm{Cd}$ accumulation $(+)$; Negative loads indicated Cd reduction $(-)$. Percent values of actual Cd accumulation(+) or reduction $(-)$ with respect to mean calculated loads were also assessed (Table 6).

It appeared that in cultivars grown in the unpolluted soil, substantial accumulation of Cd occurred both in stem and leaf, with no definite predominance. In contrast, in seed and pod Cd loads were considerably reduced (by $13-82 \%$, mean $46.5 \%$ wt.), which may be considered as an external seed/pod protection against $\mathrm{Cd}$ accumulation.

However, there was no such clear picture in the case of soybean cultivars grown in the moderately polluted soil. Redistribution of Cd load between shoot parts was generally within a similar range as in cultivars grown in unpolluted soil, but did not show similar accumulation in stem/leaf and reduction in seed/pod, but in different cultivars displayed dissimilar pattern. This resulted in the mean reduction of $\mathrm{Cd}$ in seed by $5.6 \%$ wt only, with Cd reduction in seeds of 9 cultivars by $1.6-23.0 \% \mathrm{wt}$, but surplus accumulation by $2.4-9.8 \%$ wt in seeds of 6 cultivars (Table 6). Therefore, protective 
Table 3

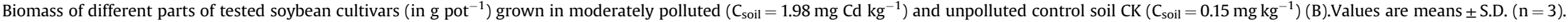

\begin{tabular}{|c|c|c|c|c|c|c|c|c|c|c|c|c|c|c|c|c|}
\hline \multirow[t]{2}{*}{ Culti-var* } & \multicolumn{16}{|c|}{ (A) Cd concentration in soil $1.98 \mathrm{mg} \mathrm{kg}^{-1}$} \\
\hline & D8 & D3 & D2 & D15 & D14 & D11 & D4 & D12 & D9 & D1 & D5 & D10 & D6 & D7 & D13 & Mean \\
\hline Root & $\begin{array}{l}4.18 \pm \\
0.69 \mathrm{e} A \mathrm{~B}\end{array}$ & $\begin{array}{l}5.35 \pm \\
1.22 \mathrm{dcA}\end{array}$ & $\begin{array}{l}5.73 \pm \\
1.04 \mathrm{cA}\end{array}$ & $\begin{array}{l}5.88 \pm \\
0.63 \mathrm{cA}\end{array}$ & $\begin{array}{l}6.19_{ \pm} \\
0.44 \mathrm{abA}\end{array}$ & $\begin{array}{l}5.56 \pm \\
0.55 \mathrm{bA}\end{array}$ & $\begin{array}{l}5.72 \pm \\
0.97 \mathrm{cA}\end{array}$ & $\begin{array}{l}6.05 \pm \\
0.34 \mathrm{bcA}\end{array}$ & $\begin{array}{l}5.18 \pm \\
0.54 \mathrm{dA}\end{array}$ & $\begin{array}{l}3.30_{ \pm} \\
0.79 \mathrm{fB}\end{array}$ & $\begin{array}{l}4.95 \pm \\
1.01 \mathrm{dA}\end{array}$ & $\begin{array}{l}5.88_{ \pm} \\
0.62 \mathrm{cA}\end{array}$ & $\begin{array}{l}5.48 \pm \\
0.35 \mathrm{cA}\end{array}$ & $\begin{array}{l}6.24 \pm \\
0.54 \mathrm{aA}\end{array}$ & $\begin{array}{l}5.53 \pm \\
0.30 \mathrm{cA}\end{array}$ & $\begin{array}{l}6.36 \pm \\
0.50\end{array}$ \\
\hline Shoot & $\begin{array}{l}40.98 \pm \\
0.31 \mathrm{bA}\end{array}$ & $\begin{array}{l}53.68 \pm \\
0.79 \mathrm{aA}\end{array}$ & $\begin{array}{l}56.19 \pm \\
0.79 \mathrm{aA}\end{array}$ & $\begin{array}{l}53.89 \pm \\
0.94 \mathrm{aA}\end{array}$ & $\begin{array}{l}56.25 \pm \\
1.41 \mathrm{aA}\end{array}$ & $\begin{array}{l}55.31 \pm \\
0.34 \mathrm{aA}\end{array}$ & $\begin{array}{l}47.68 \pm \\
1.97 \mathrm{aA}\end{array}$ & $\begin{array}{l}58.79 \pm \\
0.21 \mathrm{aA}\end{array}$ & $\begin{array}{l}53.92 \pm \\
0.24 \mathrm{aA}\end{array}$ & $\begin{array}{l}30.76 \pm \\
3.69 \mathrm{cB}\end{array}$ & $\begin{array}{l}49.92 \pm \\
1.01 \mathrm{aA}\end{array}$ & $\begin{array}{l}54.13 \pm \\
0.83 \mathrm{aA}\end{array}$ & $\begin{array}{l}51.77 \pm \\
1.34 \mathrm{aA}\end{array}$ & $\begin{array}{l}58.01 \pm \\
2.27 \mathrm{aA}\end{array}$ & $\begin{array}{l}53.12 \pm \\
0.78 \mathrm{aA}\end{array}$ & $\begin{array}{l}56.47 \pm \\
5.70\end{array}$ \\
\hline Bean & $\begin{array}{l}13.84 \pm \\
0.82 \mathrm{cAB}\end{array}$ & $\begin{array}{l}21.23 \pm \\
1.06 \mathrm{abA}\end{array}$ & $\begin{array}{l}21.81 \pm \\
0.96 \mathrm{aA}\end{array}$ & $\begin{array}{l}21.51 \pm \\
0.87 \mathrm{aA}\end{array}$ & $\begin{array}{l}21.89 \pm \\
0.44 \mathrm{aA}\end{array}$ & $\begin{array}{l}22.26 \pm \\
0.88 \mathrm{aA}\end{array}$ & $\begin{array}{l}18.52 \pm \\
1.19 \mathrm{bA}\end{array}$ & $\begin{array}{l}22.83 \pm \\
0.58 \mathrm{aA}\end{array}$ & $\begin{array}{l}21.64 \pm \\
0.86 \mathrm{aA}\end{array}$ & $\begin{array}{l}9.90 \pm \\
1.11 \mathrm{~dB}\end{array}$ & $\begin{array}{l}19.48 \pm \\
1.21 \mathrm{abA}\end{array}$ & $\begin{array}{l}19.48 \pm \\
1.21 \mathrm{abA}\end{array}$ & $\begin{array}{l}20.64 \pm \\
0.63 \mathrm{abA}\end{array}$ & $\begin{array}{l}21.96 \pm \\
0.59 \mathrm{aA}\end{array}$ & $\begin{array}{l}21.32 \pm \\
0.29 \mathrm{abA}\end{array}$ & $\begin{array}{l}21.44 \pm \\
2.58\end{array}$ \\
\hline Pod & $\begin{array}{l}8.50 \pm \\
0.55 \mathrm{bA}\end{array}$ & $\begin{array}{l}10.63 \pm \\
0.92 \mathrm{aA}\end{array}$ & $\begin{array}{l}10.72 \pm \\
2.43 \mathrm{aA}\end{array}$ & $\begin{array}{l}9.82 \pm \\
0.58 \mathrm{abA}\end{array}$ & $\begin{array}{l}10.46 \pm \\
1.19 \mathrm{aA}\end{array}$ & $\begin{array}{l}10.01 \pm \\
0.38 \mathrm{aA}\end{array}$ & $\begin{array}{l}9.20 \pm \\
0.96 \mathrm{abA}\end{array}$ & $\begin{array}{l}10.89 \pm \\
0.37 \mathrm{aA}\end{array}$ & $\begin{array}{l}9.61 \pm \\
1.03 \mathrm{abA}\end{array}$ & $\begin{array}{l}5.33 \pm \\
0.98 \mathrm{cB}\end{array}$ & $\begin{array}{l}9.89 \pm \\
0.36 \mathrm{abA}\end{array}$ & $\begin{array}{l}9.89_{ \pm} \\
0.36 \mathrm{abA}\end{array}$ & $\begin{array}{l}8.67 \pm \\
0.52 \mathrm{bA}\end{array}$ & $\begin{array}{l}11.43 \pm \\
0.66 \mathrm{aA}\end{array}$ & $\begin{array}{l}9.61 \pm \\
0.70 \mathrm{abA}\end{array}$ & $\begin{array}{l}10.81 \pm \\
1.26\end{array}$ \\
\hline Stem & $\begin{array}{l}10.55 \pm \\
0.70 \mathrm{cAB}\end{array}$ & $\begin{array}{l}12.15_{ \pm} \\
1.10 \mathrm{abA}\end{array}$ & $\begin{array}{l}13.43 \pm \\
1.89 \mathrm{abA}\end{array}$ & $\begin{array}{l}12.23 \pm \\
0.86 \mathrm{~b} A\end{array}$ & $\begin{array}{l}14.78 \pm \\
0.54 \mathrm{aA}\end{array}$ & $\begin{array}{l}13.88 \pm \\
0.75 \mathrm{abA}\end{array}$ & $\begin{array}{l}11.84 \pm \\
1.09 \mathrm{cA}\end{array}$ & $\begin{array}{l}13.83 \pm \\
0.28 \mathrm{abA}\end{array}$ & $\begin{array}{l}12.82 \pm \\
0.99 a b A\end{array}$ & $\begin{array}{l}8.19_{ \pm} \\
1.82 \mathrm{~dB}\end{array}$ & $\begin{array}{l}12.31 \pm \\
0.93 \mathrm{abA}\end{array}$ & $\begin{array}{l}14.28 \pm \\
0.68 \mathrm{aA}\end{array}$ & $\begin{array}{l}13.98 \pm \\
1.24 \mathrm{aA}\end{array}$ & $\begin{array}{l}13.76 \pm \\
0.54 \mathrm{aA}\end{array}$ & $\begin{array}{l}12.06 \pm \\
0.68 \mathrm{bcA}\end{array}$ & $\begin{array}{l}13.83 \pm \\
1.43\end{array}$ \\
\hline Leaf & $\begin{array}{l}8.10_{ \pm} \\
0.82 \mathrm{cA}\end{array}$ & $\begin{array}{l}9.66 \pm \\
1.25 \mathrm{abA}\end{array}$ & $\begin{array}{l}10.23 \pm \\
2.10 \mathrm{abA}\end{array}$ & $\begin{array}{l}10.33 \pm \\
0.95 \mathrm{abA}\end{array}$ & $\begin{array}{l}9.12_{ \pm} \\
0.58 \mathrm{bA}\end{array}$ & $\begin{array}{l}9.16 \pm \\
0.59 \mathrm{bA}\end{array}$ & $\begin{array}{l}8.12 \pm \\
0.99 \mathrm{cA}\end{array}$ & $\begin{array}{l}11.25 \pm \\
0.28 \mathrm{aA}\end{array}$ & $\begin{array}{l}9.85 \pm \\
1.02 \mathrm{abA}\end{array}$ & $\begin{array}{l}7.35 \pm \\
1.72 \mathrm{cA}\end{array}$ & $\begin{array}{l}8.24 \pm \\
0.44 \mathrm{cA}\end{array}$ & $\begin{array}{l}9.07 \pm \\
0.97 \mathrm{bA}\end{array}$ & $\begin{array}{l}8.48 \pm \\
0.67 \mathrm{cA}\end{array}$ & $\begin{array}{l}10.85 \pm \\
0.55 \mathrm{aA}\end{array}$ & $\begin{array}{l}10.14 \pm \\
0.78 \mathrm{abA}\end{array}$ & $\begin{array}{l}10.40_{ \pm} \\
0.87\end{array}$ \\
\hline (B) $\mathrm{Cd} \mathrm{cc}$ & tration in & polluted $s$ & $0.15 \mathrm{mg} \mathrm{k}$ & ${ }^{1}(\mathrm{CK})$ & & & & & & & & & & & & \\
\hline Root & $\begin{array}{l}5.71 \pm \\
0.44 \mathrm{bcA}\end{array}$ & $\begin{array}{l}6.11 \pm \\
1.10 \mathrm{abA}\end{array}$ & $\begin{array}{l}6.34 \pm \\
0.45 \mathrm{abA}\end{array}$ & $\begin{array}{l}6.23 \pm \\
0.31 \mathrm{abA}\end{array}$ & $\begin{array}{l}7.01 \pm \\
0.48 \mathrm{aA}\end{array}$ & $\begin{array}{l}6.78 \pm \\
0.59 \mathrm{aA}\end{array}$ & $\begin{array}{l}6.05 \pm \\
0.14 \mathrm{abA}\end{array}$ & $\begin{array}{l}6.55 \pm \\
0.88 \mathrm{aA}\end{array}$ & $\begin{array}{l}6.12 \pm \\
0.43 \mathrm{abA}\end{array}$ & $\begin{array}{l}5.39 \pm \\
0.91 \mathrm{cA}\end{array}$ & $\begin{array}{l}6.13 \pm \\
0.93 \mathrm{abA}\end{array}$ & $\begin{array}{l}7.12 \pm \\
0.30 \mathrm{abA}\end{array}$ & $\begin{array}{l}6.83 \pm \\
0.81 \mathrm{aA}\end{array}$ & $\begin{array}{l}6.96 \pm \\
0.68 \mathrm{aA}\end{array}$ & $\begin{array}{l}6.12 \pm \\
0.36 \mathrm{abA}\end{array}$ & $\begin{array}{l}5.41 \pm \\
0.79\end{array}$ \\
\hline Shoot & $\begin{array}{l}48.56 \pm \\
1.53 \mathrm{abA}\end{array}$ & $\begin{array}{l}56.95 \pm \\
2.23 \mathrm{aA}\end{array}$ & $\begin{array}{l}59.23 \pm \\
3.59 \mathrm{abA}\end{array}$ & $\begin{array}{l}58.78 \pm \\
0.34 \mathrm{abAA}\end{array}$ & $\begin{array}{l}60.15 \pm \\
0.99 \mathrm{abA}\end{array}$ & $\begin{array}{l}59.20 \pm \\
0.20 \mathrm{aA}\end{array}$ & $\begin{array}{l}53.62 \pm \\
0.36 \mathrm{bA}\end{array}$ & $\begin{array}{l}61.29 \pm \\
1.15 \mathrm{aA}\end{array}$ & $\begin{array}{l}56.51 \pm \\
1.20 \mathrm{abA}\end{array}$ & $\begin{array}{l}10.09_{ \pm} \\
0.78 \mathrm{cB}\end{array}$ & $\begin{array}{l}53.83 \pm \\
0.18 \mathrm{bA}\end{array}$ & $\begin{array}{l}60.40 \pm \\
0.85 \mathrm{aA}\end{array}$ & $\begin{array}{l}58.44 \pm \\
1.42 \mathrm{abA}\end{array}$ & $\begin{array}{l}61.95 \pm \\
0.67 \mathrm{aA}\end{array}$ & $\begin{array}{l}58.11 \pm \\
1.14 \mathrm{abA}\end{array}$ & $\begin{array}{l}51.63 \pm \\
7.26\end{array}$ \\
\hline Bean & $\begin{array}{l}17.44 \pm \\
0.99 \mathrm{bB}\end{array}$ & $\begin{array}{l}21.56 \pm \\
1.07 \mathrm{aA}\end{array}$ & $\begin{array}{l}22.37 \pm \\
0.45 \mathrm{aA}\end{array}$ & $\begin{array}{l}22.68 \pm \\
0.69 \mathrm{aA}\end{array}$ & $\begin{array}{l}23.02 \pm \\
0.70 \mathrm{aA}\end{array}$ & $\begin{array}{l}23.11 \pm \\
0.54 \mathrm{aA}\end{array}$ & $\begin{array}{l}20.18 \pm \\
0.49 \mathrm{abA}\end{array}$ & $\begin{array}{l}23.24 \pm \\
0.84 \mathrm{aA}\end{array}$ & $\begin{array}{l}22.18 \pm \\
0.19 \mathrm{aA}\end{array}$ & $\begin{array}{l}14.16 \pm \\
1.27 \mathrm{cB}\end{array}$ & $\begin{array}{l}20.04 \pm \\
1.59 \mathrm{abAB}\end{array}$ & $\begin{array}{l}23.14 \pm \\
0.74 \mathrm{aA}\end{array}$ & $\begin{array}{l}22.83 \pm \\
0.44 \mathrm{aA}\end{array}$ & $\begin{array}{l}23.21 \pm \\
0.65 \mathrm{aA}\end{array}$ & $\begin{array}{l}22.39 \pm \\
0.50 \mathrm{aA}\end{array}$ & $\begin{array}{l}19.99_{ \pm} \\
3.54\end{array}$ \\
\hline Pod & $\begin{array}{l}9.12 \pm \\
0.57 \mathrm{bAB}\end{array}$ & $\begin{array}{l}11.24 \pm \\
1.11 \mathrm{aA}\end{array}$ & $\begin{array}{l}11.91 \pm \\
0.60 \mathrm{aA}\end{array}$ & $\begin{array}{l}10.98 \pm \\
0.75 \mathrm{abA}\end{array}$ & $\begin{array}{l}11.91 \pm \\
0.76 \mathrm{aA}\end{array}$ & $\begin{array}{l}10.98 \pm \\
0.78 \mathrm{abA}\end{array}$ & $\begin{array}{l}10.44 \pm \\
036 \mathrm{bA}\end{array}$ & $\begin{array}{l}11.21 \pm \\
0.36 \mathrm{aA}\end{array}$ & $\begin{array}{l}10.88 \pm \\
0.68 \mathrm{abA}\end{array}$ & $\begin{array}{l}7.24 \pm \\
1.06 \mathrm{cB}\end{array}$ & $\begin{array}{l}10.68 \pm \\
0.80 \mathrm{abA}\end{array}$ & $\begin{array}{l}11.17 \pm \\
0.60 \mathrm{aA}\end{array}$ & $\begin{array}{l}10.81 \pm \\
052 \mathrm{abA}\end{array}$ & $\begin{array}{l}12.66 \pm \\
0.44 \mathrm{aA}\end{array}$ & $\begin{array}{l}10.87 \pm \\
0.45 \mathrm{abA}\end{array}$ & $\begin{array}{l}9.64 \pm \\
1.44\end{array}$ \\
\hline Stem & $\begin{array}{l}11.98 \pm \\
0.55 \mathrm{bA}\end{array}$ & $\begin{array}{l}13.81 \pm \\
1.80 \mathrm{abA}\end{array}$ & $\begin{array}{l}14.03 \pm \\
1.95 \mathrm{aA}\end{array}$ & $\begin{array}{l}13.67 \pm \\
0.45 \mathrm{abA}\end{array}$ & $\begin{array}{l}15.22 \pm \\
0.42 \mathrm{aA}\end{array}$ & $\begin{array}{l}14.99 \pm \\
0.81 \mathrm{aA}\end{array}$ & $\begin{array}{l}13.19 \pm \\
0.19 \mathrm{abA}\end{array}$ & $\begin{array}{l}14.76 \pm \\
0.65 \mathrm{aA}\end{array}$ & $\begin{array}{l}13.33 \pm \\
0.89 \mathrm{abA}\end{array}$ & $\begin{array}{l}10.01 \pm \\
1.37 \mathrm{cA}\end{array}$ & $\begin{array}{l}13.54 \pm \\
1.24 \mathrm{abA}\end{array}$ & $\begin{array}{l}15.77 \pm \\
0.58 \mathrm{aA}\end{array}$ & $\begin{array}{l}14.88 \pm \\
0.54 \mathrm{aA}\end{array}$ & $\begin{array}{l}14.72 \pm \\
0.40 \mathrm{aA}\end{array}$ & $\begin{array}{l}13.54 \pm \\
0.36 \mathrm{abA}\end{array}$ & $\begin{array}{l}12.67 \pm \\
1.68\end{array}$ \\
\hline Leaf & $\begin{array}{l}10.02 \pm \\
0.46 \mathrm{bA}\end{array}$ & $\begin{array}{l}10.34 \pm \\
0.34 \mathrm{abA}\end{array}$ & $\begin{array}{l}10.92 \pm \\
1.77 \mathrm{aA}\end{array}$ & $\begin{array}{l}11.45 \pm \\
0.46 \mathrm{aA}\end{array}$ & $\begin{array}{l}10.00 \pm \\
0.29 \mathrm{bA}\end{array}$ & $\begin{array}{l}10.12 \pm \\
0.82 \mathrm{abA}\end{array}$ & $\begin{array}{l}9.81 \pm \\
036 \mathrm{bA}\end{array}$ & $\begin{array}{l}12.07 \pm \\
0.69 \mathrm{aA}\end{array}$ & $\begin{array}{l}10.12 \pm \\
0.85 \mathrm{abA}\end{array}$ & $\begin{array}{l}8.69_{ \pm} \\
1.11 \mathrm{bA}\end{array}$ & $\begin{array}{l}9.57 \pm \\
0.58 \mathrm{bA}\end{array}$ & $\begin{array}{l}10.32 \pm \\
0.76 \mathrm{aA}\end{array}$ & $\begin{array}{l}9.93 \pm \\
0.52 \mathrm{bA}\end{array}$ & $\begin{array}{l}11.36 \pm \\
0.69 \mathrm{aA}\end{array}$ & $\begin{array}{l}11.31 \pm \\
0.63 \mathrm{aA}\end{array}$ & $\begin{array}{l}9.33 \pm \\
1.13\end{array}$ \\
\hline
\end{tabular}

${ }^{*}$ Cultivars aligned in the order according to increasing $\mathrm{Cd}$ concentrations in beans grown in moderately polluted soil containing $1.98 \mathrm{mg} \mathrm{Cd} \mathrm{kg}^{-1}$. Data in a line followed by the same lowercase letters are not significantly different at $p<0.05$, and by the same capital letters - at $p<0.01$. 


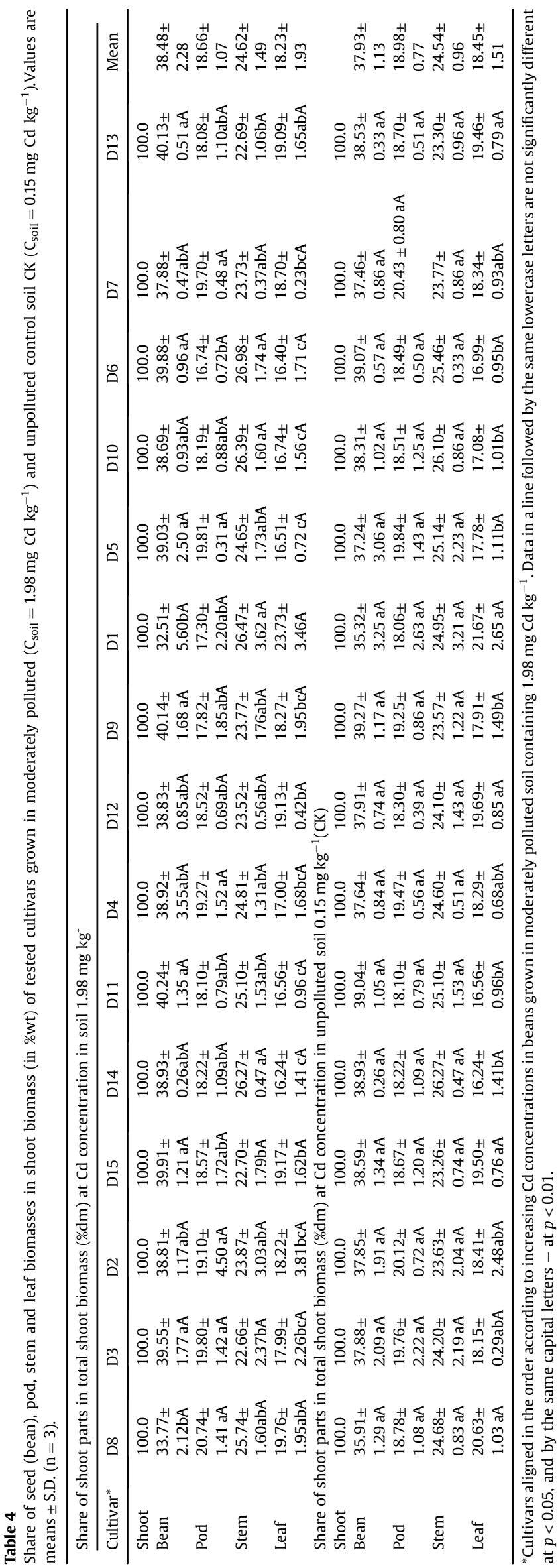

role of load redistribution in this case appeared to be marginal.

Overall major observation that can be derived from this study is a thoroughly different $\mathrm{Cd}$ accumulative behavior of soybean cultivars grown in unpolluted and moderately polluted soil. This is due to the domination of different $\mathrm{Cd}$ enrichment/protection mechanisms of plants related to Cd uptake by roots, its translocation, accumulation in different plant parts and specific protective capacity of seed (bean). (Figs. 1 and 5).

\section{Discussion}

\subsection{Food safety and Cd accumulation properties of soybean cultivars}

It appeared that entirely concentrations of Cd in seeds (bean) of 15 tested soybean cultivars grown in the natural unpolluted soil $\left(C_{\text {Soil }}=0.15 \mathrm{mg} \mathrm{Cd} \mathrm{kg}^{-1}\right.$ ) (Fig. 1B), were below the Maximum Level of Contaminants in Foods (MLs) for soybean that accounts for $0.20 \mathrm{mg} \mathrm{Cd} \mathrm{kg}^{-1}$, according to the international (Codex Alimentarius Commission, 2001) and national Food Quality Standards (MHC, 2013).

Conversely, all $\mathrm{Cd}$ concentrations in beans of cultivars grown in the moderately polluted soil $\left(\mathrm{C}_{\text {Soil }}=1.98 \mathrm{mg} \mathrm{Cd} \mathrm{kg}^{-1}\right)$ exceeded MLs. Thus, none of the investigated cultivars may be considered Cdexcluder, and only 6 ones (D8, D3, D2, D15, D14 and D11) fulfilled elevated standards for feedstuff $\left(<0.5 \mathrm{mg} \mathrm{Cd} \mathrm{kg}^{-1}\right)$, if grown in even moderately polluted soil (CECSPC, 2009). Moreover, D12 cultivar (Tiefeng 31) that was considered as a potential Cd-excluder (Zhi et al., 2015), at $1.98 \mathrm{mg} \mathrm{Cd} \mathrm{kg}^{-1}$ in soil did not show high resistance against $\mathrm{Cd}$ accumulation in seeds (Fig. 1A-seed). The results show that soybean cultivars have high $\mathrm{Cd}$ accumulation properties, in particular in the edible parts that are seeds (beans), and indicate the general lack or weak protective mechanisms against Cd uptake and translocation to beans. These observations confirm susceptibility of soybean to $\mathrm{Cd}$ pollution reported in the different regions of the world -in the USA (Page et al., 1987), Japan (Kobori et al., 2011), Argentina (Salazar et al., 2012), Nigeria (Orisakwe et al., 2012) and China (Zhao et al., 2014). Therefore, a particular attention should be paid to soybean safety as a food/feed.

\subsection{Occurrence and role of seed (bean) enrichment/protection mechanisms in soybean}

The differences in Cd enrichment in different soybean cultivars grown under the same environmental conditions, discriminate two major groups of cultivars grown in the moderately $\mathrm{Cd}$ polluted soil, i.e. those showing a moderate $\mathrm{Cd}$ accumulation (D8 $<$ D3 $<$ D2 $<$ D15 $<$ D14 $<$ D11), and other ones with considerably higher Cd accumulation in beans. This suggests the predominantly genetic origin of these differences, which is in line with other observations (Arao et al., 2003) further confirmed (Ishikawa et al., 2005) and developed (Kobori et al., 2011), and some genetic/ genomic studies (Jegadeesan et al., 2016).

The major focus and novel finding of our research is variability of Cd translocation/accumulation in exactly the same soybean plants and their parts, and in consequence different role of related seed protective mechanisms depending on the extent of soil contamination with $\mathrm{Cd}$. Up to now, these issues have not been noticed, although protective role of $\mathrm{Cd}$ accumulation in plant parts, in particular in roots (Sugiyama et al., 2007) and leaves (Sugiyama, 2009), and self-protection/detoxification mechanisms in seeds has been reported previously (Clemens, 2006).

An important, not yet discussed question, is changeable Cd load distribution in soybean tissues. Due to biomass distribution pattern common to all studied cultivars and independent on Cd content in 


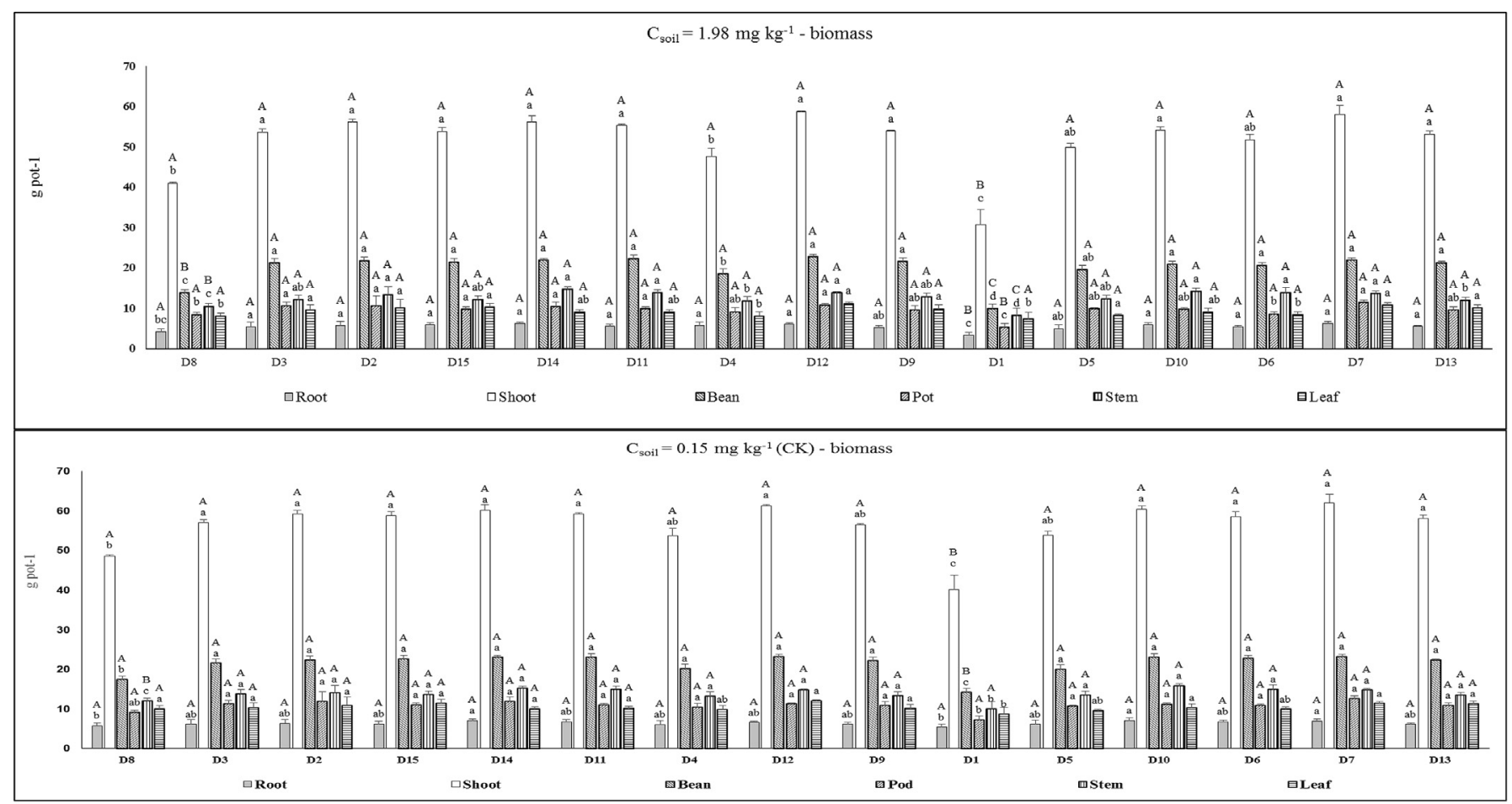

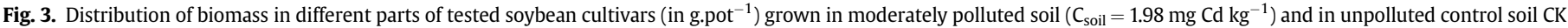

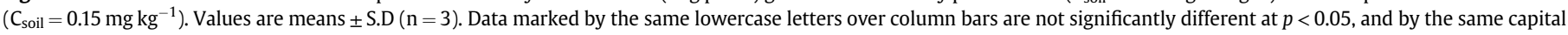
letters - at $p<0.01$.

Table 5

The effect of soil pollution with cadmium on soybean biomass yield.

\begin{tabular}{|c|c|c|c|c|c|c|}
\hline \multirow[t]{2}{*}{ Cultivar $^{*}$} & \multicolumn{6}{|c|}{ Yield reduction (in \%wt) } \\
\hline & Root & Shoot & Seed (Bean) & Pod & Stem & Leaf \\
\hline D8 & $26.42 \pm 14.04 \mathrm{bAB}$ & $15.54 \pm 3.14 \mathrm{bAB}$ & $20.57 \pm 5.18 \mathrm{bA}$ & $6.80 \pm 3.47 \mathrm{dC}$ & $11.75 \pm 8.54 \mathrm{bB}$ & $18.86 \pm 11.19 \mathrm{aA}$ \\
\hline D3 & $12.73 \pm 6.22 \mathrm{dC}$ & $5.69 \pm 2.32 \mathrm{fgDE}$ & $1.27 \pm 8.43 \mathrm{hE}$ & $4.57 \pm 14.21 \mathrm{eCD}$ & $10.47 \pm 18.62 b B$ & $6.40 \pm 13.53 \mathrm{dC}$ \\
\hline D2 & $8.80 \pm 21.08 \mathrm{efC}$ & $4.88 \pm 6.39 \mathrm{~g}$ & $2.43 \pm 6.03 \mathrm{gD}$ & $10.46 \pm 16.29 \mathrm{cB}$ & $2.33 \pm 23.16 \mathrm{eD}$ & $2.81 \pm 23.28 \mathrm{fDE}$ \\
\hline D15 & $5.44 \pm 11.36 \mathrm{gD}$ & $8.31 \pm 1.90 \mathrm{deCD}$ & $5.17 \pm 1.77 \mathrm{eC}$ & $10.31 \pm 7.35 \mathrm{cB}$ & $10.50 \pm 6.63 \mathrm{bB}$ & $9.62 \pm 10.11 \mathrm{cB}$ \\
\hline D14 & $11.24 \pm 11.78 \mathrm{deC}$ & $6.48 \pm 1.95 \mathrm{fD}$ & $4.84 \pm 3.69 \mathrm{eC}$ & $12.33 \pm 4.32 \mathrm{cB}$ & $2.89 \pm 3.34 \mathrm{eD}$ & $8.77 \pm 6.01 \mathrm{cBC}$ \\
\hline D11 & $17.27 \pm 14.28 \mathrm{cB}$ & $6.58 \pm 0.58 \mathrm{fD}$ & $3.63 \pm 5.14 \mathrm{fC}$ & $8.44 \pm 8.69 \mathrm{dBC}$ & $7.18 \pm 8.20 \mathrm{cdBC}$ & $8.90 \pm 11.72 \mathrm{cB}$ \\
\hline D4 & $5.34 \pm 17.88 \mathrm{gD}$ & $11.06 \pm 4.27 \mathrm{cB}$ & $8.28 \pm 3.74 \mathrm{cdB}$ & $11.75 \pm 10.62 \mathrm{cB}$ & $10.28 \pm 7.00 \mathrm{bB}$ & $17.35 \pm 8.31 \mathrm{aA}$ \\
\hline D12 & $7.10 \pm 7.01 \mathrm{fCD}$ & $4.05 \pm 1.55 \mathrm{gE}$ & $1.72 \pm 2.75 \mathrm{hD}$ & $2.78 \pm 6.23 \mathrm{D}$ & $6.23 \pm 3.70 \mathrm{dC}$ & $6.68 \pm 3.93 \mathrm{dC}$ \\
\hline D9 & $15.08 \pm 9.01 \mathrm{cB}$ & $4.56 \pm 1.76 \mathrm{gE}$ & $2.42 \pm 4.29 \mathrm{gCD}$ & $11.33 \pm 12.26 \mathrm{cB}$ & $3.32 \pm 12.14 \mathrm{CD}$ & $1.65 \pm 18.24 \mathrm{gE}$ \\
\hline D1 & $39.14 \pm 7.01 \mathrm{aA}$ & $23.29 \pm 8.71 \mathrm{aA}$ & $29.86 \pm 8.12 \mathrm{aA}$ & $26.57 \pm 5.35 \mathrm{aA}$ & $16.66 \pm 25.63 \mathrm{aA}$ & $13.81 \pm 27.95 \mathrm{bA}$ \\
\hline D5 & $16.14 \pm 30.52 \mathrm{cB}$ & $7.26 \pm 1.86 \mathrm{efD}$ & $2.63 \pm 4.77 \mathrm{gD}$ & $7.02 \pm 8.25 \mathrm{dC}$ & $9.00 \pm 1.67 \mathrm{bcB}$ & $13.63 \pm 7.24 \mathrm{bAB}$ \\
\hline D10 & $17.31 \pm 8.65 \mathrm{cB}$ & $10.38 \pm 0.51 \mathrm{cB}$ & $9.45 \pm 2.75 \mathrm{cB}$ & $11.84 \pm 2.00 \mathrm{cB}$ & $9.30 \pm 6.78 \mathrm{bcB}$ & $12.32 \pm 3.07 \mathrm{bB}$ \\
\hline D6 & $18.94 \pm 11.54 \mathrm{cB}$ & $11.35 \pm 4.29 \mathrm{cB}$ & $9.56 \pm 2.48 \mathrm{cB}$ & $19.52 \pm 8.85 \mathrm{bA}$ & $5.75 \pm 11.66 \mathrm{dC}$ & $14.51 \pm 6.98 \mathrm{bA}$ \\
\hline D7 & $10.18 \pm 5.87 \mathrm{eC}$ & $6.38 \pm 2.84 \mathrm{D}$ & $5.32 \pm 3.19 \mathrm{eC}$ & $9.62 \pm 6.08 \mathrm{cB}$ & $6.48 \pm 4.11 \mathrm{dC}$ & $4.40 \pm 4.75 \mathrm{eD}$ \\
\hline D13 & $9.43 \pm 7.42 \mathrm{eC}$ & $8.55 \pm 3.04 \mathrm{deD}$ & $4.77 \pm 3.07 \mathrm{efC}$ & $11.33 \pm 9.81 \mathrm{cB}$ & $10.92 \pm 4.85 \mathrm{bB}$ & $10.34 \pm 6.01 \mathrm{cB}$ \\
\hline Mean & $14.70 \pm 8.86$ & $8.96 \pm 5.03$ & $7.46 \pm 7.87$ & $10.98 \pm 5.79$ & $8.20 \pm 3.86$ & $10.00 \pm 5.11$ \\
\hline
\end{tabular}

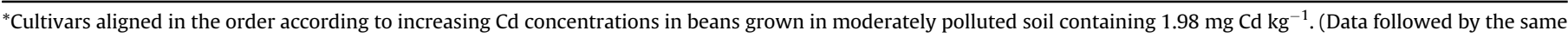
lowercase letters in the same column are not significantly different at $p<0.05$, and by the same capital letters - at $p<0.01$ ).

soil (Fig. 4), much higher Cd concentration in root than in shoot and its tissues at the moderate soil pollution did not result in adequately high Cd load in roots, while Cd loads in stem and their protective role was mostly at the similar level or higher than in leaves (Fig. 5A and B vs. Fig. 1 A,B, Table 6).

Another crucial finding of this study is the lack of conformity between $\mathrm{Cd}$ concentration/load trends in plant tissues, and specifically in seeds (beans) of the same cultivars grown in soils with low and elevated $\mathrm{Cd}$ concentration (Fig. $1 \mathrm{~A}$ and B vs. Fig. 5A and B). In cultivars grown in the unpolluted soil, at load distribution between plant tissues following an order Root «Shoot [stem $>$ leaf $>$ seed (bean) $>$ pod], both stem and leaf in the variable proportions participated in substantial surplus $\mathrm{Cd}$ accumulation, which resulted in a strong protection effect and reduction of $\mathrm{Cd}$ load in seeds by $25-82 \%$ (Table 6). Along with the relatively high individual self-protection/detoxification capacity of seed/pod, it resulted in the much lower Cd concentrations, and Cd concentration/load trend patterns for bean/pod different from those in other tissues of cultivars grown in unpolluted soil (Figs. 1B and 5B).

By contrast, in the same cultivars grown in the moderately $\mathrm{Cd}$ polluted soil, neither load redistribution, nor seed protection played any significant role (Figs. 1A and 5A). 

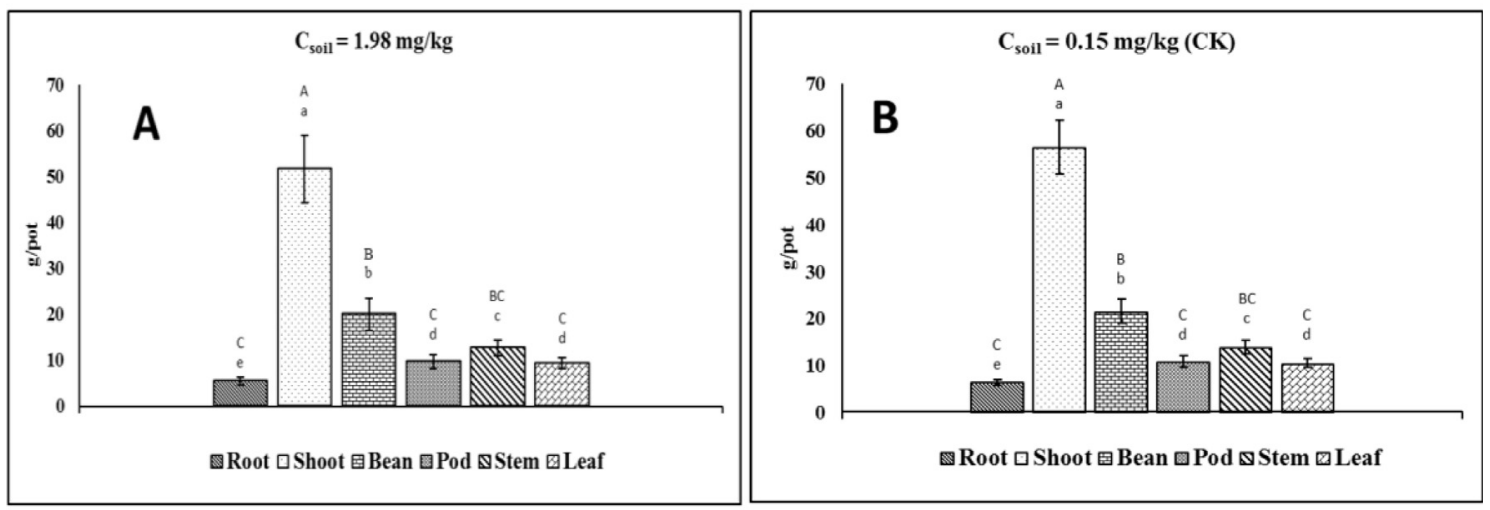

II
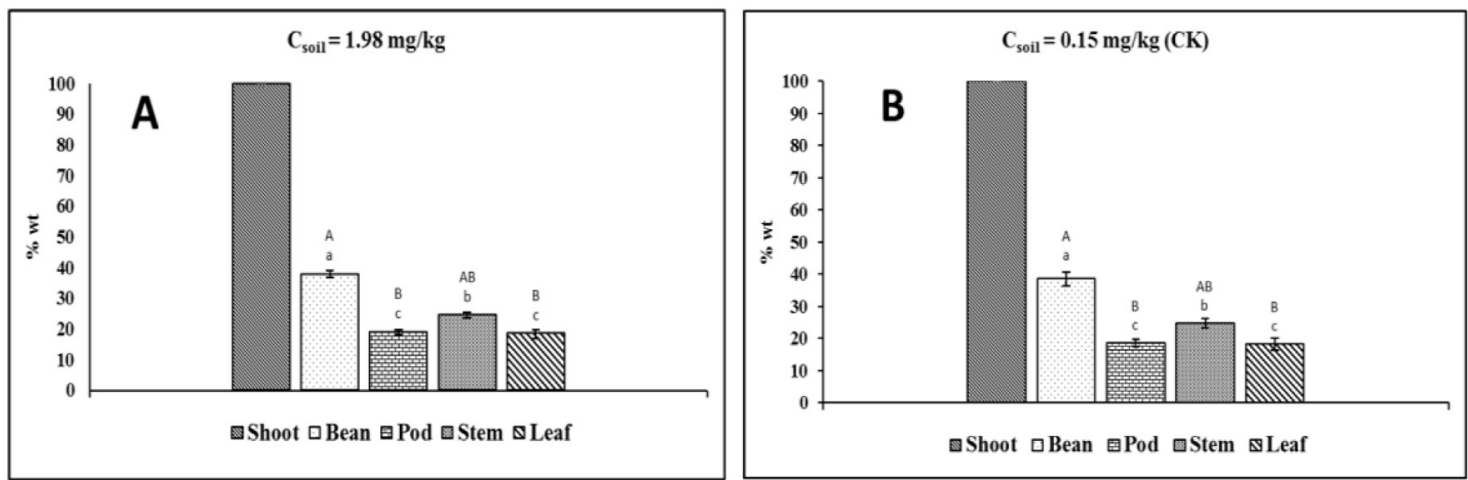

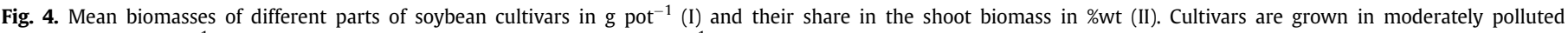
$\left(C_{\text {soil }}=1.98 \mathrm{mg} \mathrm{Cd} \mathrm{kg}^{-1}\right)(A)$ and unpolluted control soil $C K\left(C_{\text {soil }}=0.15 \mathrm{mg} \mathrm{kg}^{-1}\right)(B)$. Values are means \pm S.D. $(n=3)$.

Data for (A) and (B) in I and II marked by the same lowercase letters over column bars are not significantly different at $p<0.05$, and by the same capital letters - at $p<0.01$.

\subsection{Decisive factors in Cd accumulation in soybean seeds (beans)}

Concentration/load patterns (Figs. 1B and 5B), and EF and TF values (Fig. 3) indicate that in soybean cultivars grown in unpolluted soils, transport of $\mathrm{Cd}$ from soil and its enrichment in roots and shoots including stems and leaves occurs in principle freely and unrestrictedly, similarly to hyperaccumulators (EF $>1$ ), and according to the same trend pattern. High EF $>1$ and low accumulation in roots (TF $0.58-0.87$ ) (Fig. 3) indicated the lack of limitations of $\mathrm{Cd}$ uptake by roots from unpolluted soil and its translocation to shoots (Figs. $1 \mathrm{~B}$ and $5 \mathrm{~B}$ ). In this case, Cd accumulation in plant tissues along with control/detoxification mechanism plays a decisive role in seed/pod protection.

Contrariwise, in the same cultivars grown in the moderately polluted soil, load distribution between plant tissues followed the same order as biomass: Root $<$ Shoot [bean(seed) $>$ stem $>$ leaf $>$ pod] (see section 3.5). Under such circumstances, either stem only or predominantly (D8, D3, D2, D14, D12) or leaf only or predominantly (D15, D11, D9, D1,D5, D10, D6, D5) or both tissues, mostly at the low level (D4, D13) played protective role by accumulating extra loads. This however exerted only very minor effect on the Cd accumulation in seeds, resulting in the reduction of $\mathrm{Cd}$ load in seeds by roughly $7-23 \%$ in 7 cultivars, not causing any significant effect in 4 cultivars, while in 4 cultivars opposite process of $\mathrm{Cd}$ enrichment in seeds with respect to mean load in shoot occurred (Table 6). These data show that the protection of seed through $\mathrm{Cd}$ accumulation in different plant tissues strongly declines with increased concentration of $\mathrm{Cd}$ in soil, and becomes marginal at even moderate soil pollution within MAC range. At the weak or lacking effect of protective Cd accumulation in the parts of a plant, along with weak self-protection/detoxification capacity, Cd enrichment in seed and pod of cultivars grown in the moderately polluted soil becomes dominated by $\mathrm{Cd}$ uptake by roots and its translocation via xylem from root to shoot (Figs. 1A and 5A). It appears that not Cd accumulation in root, which plays a minor role due to low root biomass and hence low accumulated load, but the flux rate through the xylem from root to shoot is a determinant of the Cd enrichment in soybean seeds.

Relatively low biomass reduction (except D8 and D1) at weak seed $\mathrm{Cd}$ protection capacity (high $\mathrm{SAF}_{n}$ ) indicate that the tested soybean cultivars are mostly equally resistant to moderate $\mathrm{Cd}$ pollution, while $\mathrm{Cd}$ translocation rate from soil via roots to shoot is genetically differentiated. Moreover, it was noticed that high relative accumulation capacity of $\mathrm{Cd}$ by any part of a cultivar is not its specific property, but changes with Cd concentration in soil. This can be illustrated by Cd accumulation behavior of D12 (Tiefeng 31) defined by Zhi et al. (2015) as the potential Cd-excluder. Grown in the moderately polluted soil $\left(C_{\text {soil }}=1.98 \mathrm{mg} \mathrm{Cd} \mathrm{kg}^{-1}\right)$, it did not reveal any $\mathrm{Cd}$-excluding properties (Figs. $1 \mathrm{~A}$ and $5 \mathrm{~A}$, Table 6).

Besides, the major role of genetic control of $\mathrm{Cd}$ concentrations in soybean seeds (Jegadeesan et al., 2016) also seems to be limited. These limitations were illustrated by the high $0.5<\mathrm{SAF}_{\mathrm{Sh}} \geq 1.0$ values assessed for all tested cultivars grown in moderately Cd-polluted soil, which indicated low or lacking seed protection, up to excessive accumulation of $\mathrm{Cd}$ in seeds.

Instead, at the elevated $\mathrm{Cd}$ concentration in soil, the only reliable 
A
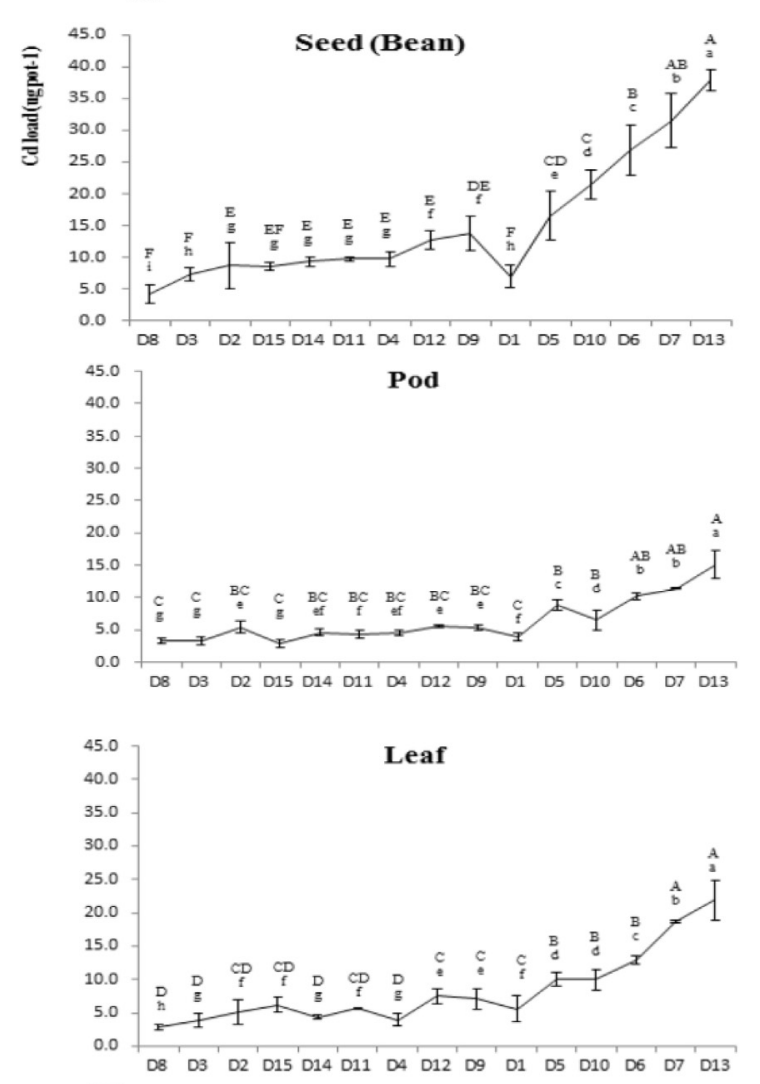

Stem

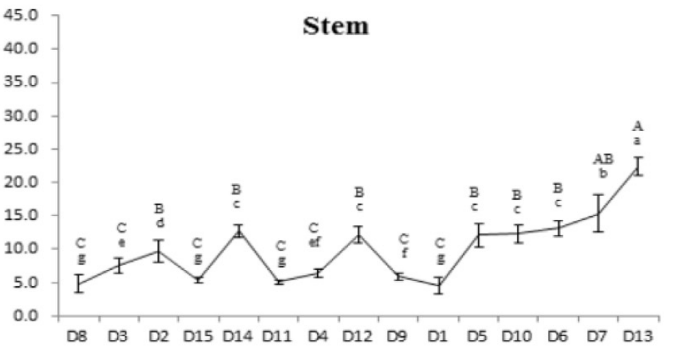

Shoot

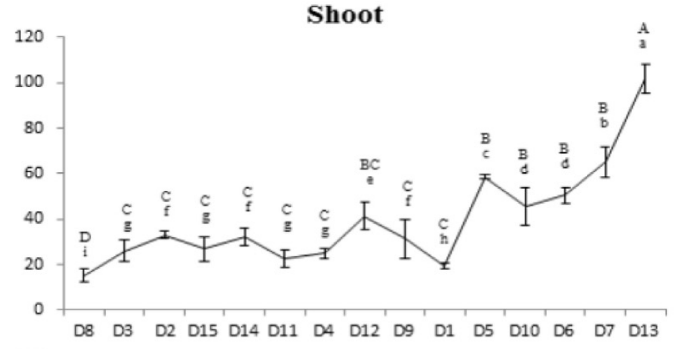

Root

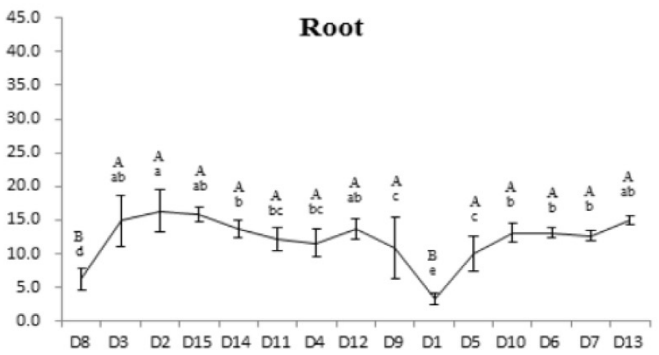

B

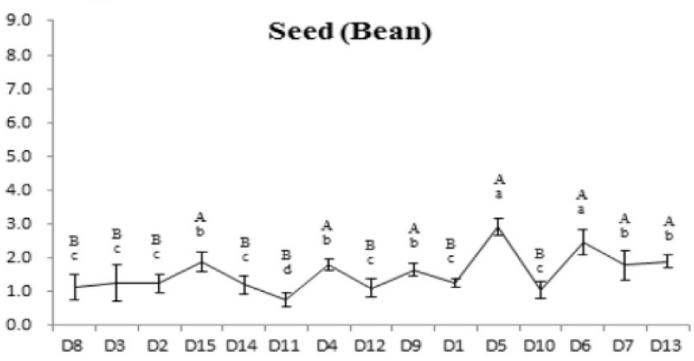

Pod

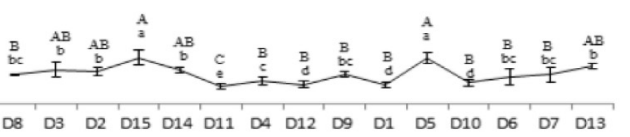

Leaf

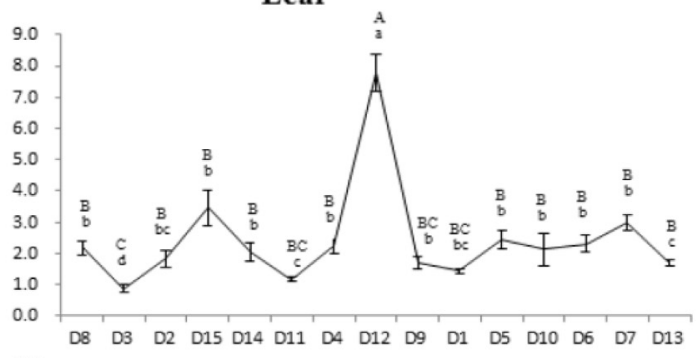

Stem

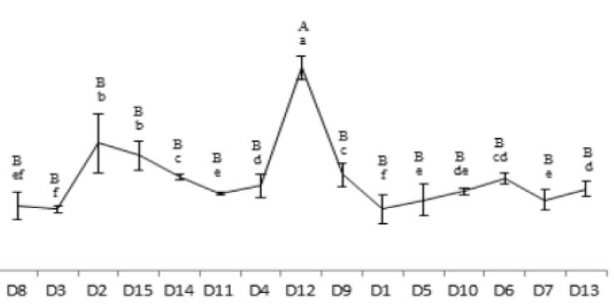

Shoot

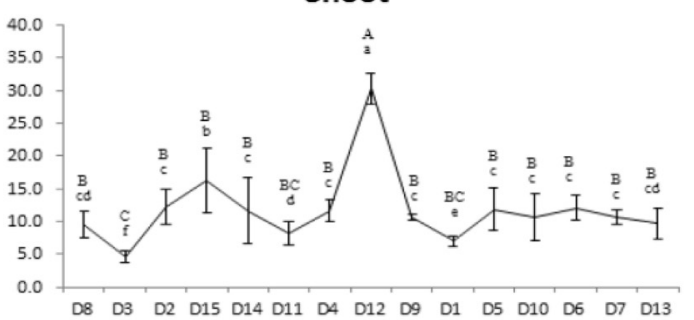

Root

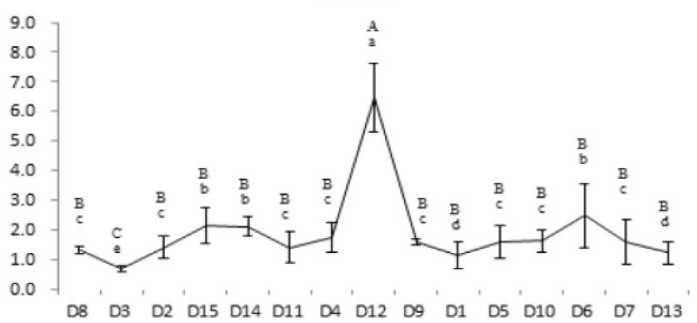

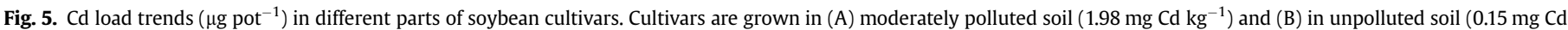
$\mathrm{kg}^{-1}$ ). Load values are aligned in the order of increasing concentrations in beans of cultivars growing in moderately polluted soil. Values are means \pm S.D. ( $\mathrm{n}=3$ ). Data marked by the same lowercase letters over points are not significantly different at $p<0.05$, and by the same capital letters - at $p<0.01$. 


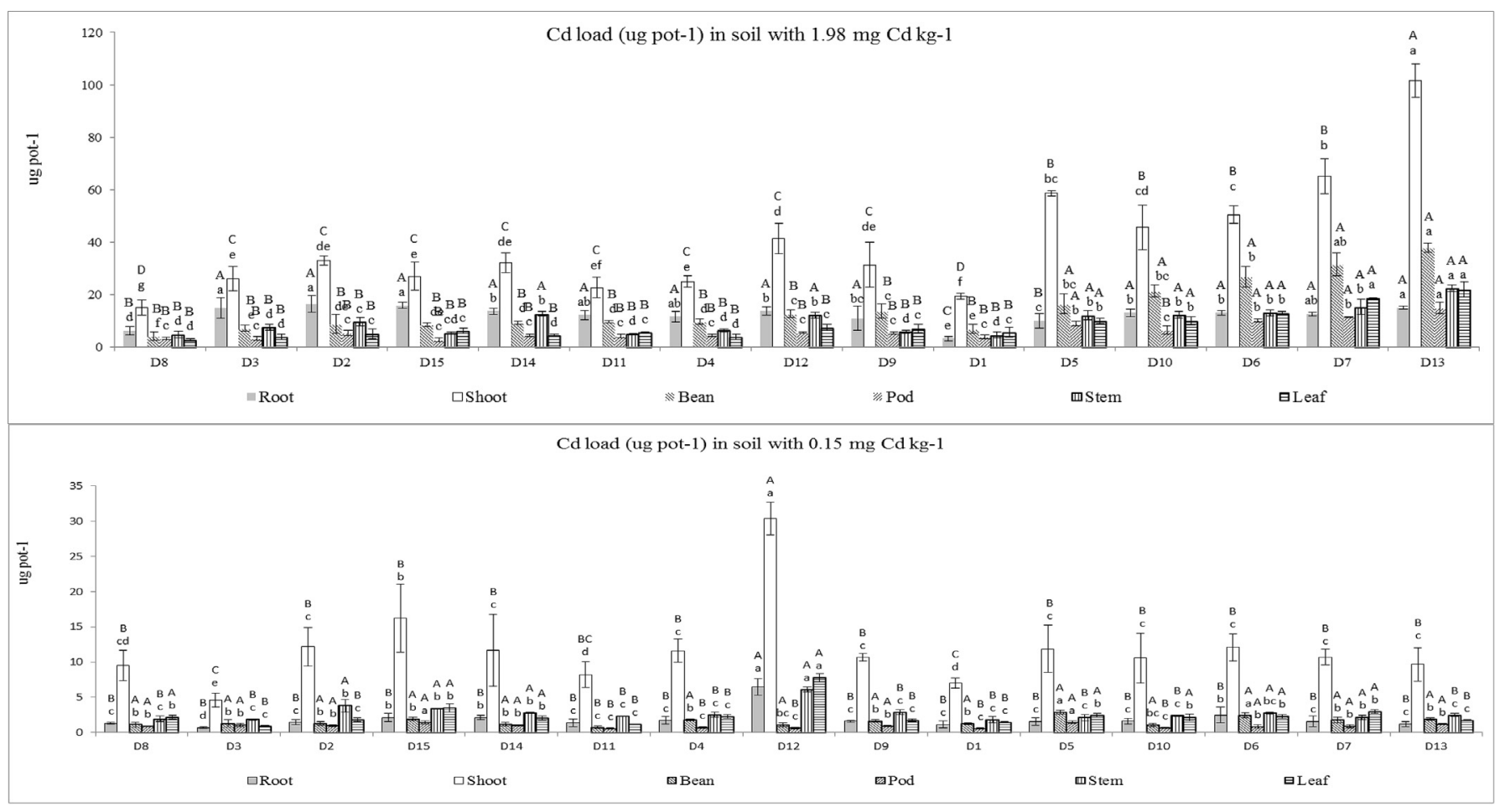

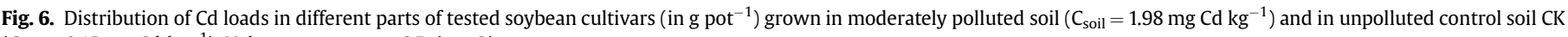
$\left(C_{\text {soil }}=0.15 \mathrm{mg} \mathrm{Cd} \mathrm{kg}^{-1}\right)$. Values are means \pm S.D $(n=3)$.

Data marked by the same lowercase letters over column bars are not significantly different at $p<0.05$, and by the same capital letters - at $p<0.01$.

Table 6

Redistribution of Cd loads in the shoot parts.

\begin{tabular}{|c|c|c|c|c|c|c|c|c|c|c|c|c|c|c|c|c|c|c|}
\hline \multirow[t]{3}{*}{ Cultivar } & \multicolumn{10}{|c|}{ Mean mass values of $\mathrm{Cd}$ accumulation $(+) /$ reduction $\left.(-)^{*}\right), \mu \mathrm{g} /$ pot } & \multicolumn{8}{|c|}{ Mean percent values of Cd accumulation $(+) /$ reduction $\left.(-)^{*}\right), \% \mathrm{wt}$} \\
\hline & \multicolumn{5}{|c|}{$\mathrm{C}_{\text {soil }}=0.15 \mathrm{mg} \mathrm{kg}^{-1}(\mathrm{CK})$} & \multicolumn{5}{|c|}{$\mathrm{C}_{\text {soil }}=1.98 \mathrm{mg} \mathrm{kg}^{-1}$} & \multicolumn{4}{|c|}{$\mathrm{C}_{\text {soil }}=0.15 \mathrm{mg} \mathrm{kg}^{-1}$} & \multicolumn{4}{|c|}{$\mathrm{C}_{\text {soil }}=1.98 \mathrm{mg} \mathrm{kg}^{-1}$} \\
\hline & Stem & Leaf & Pod & Bean & $\overline{\Delta_{\text {load }}}$ & Stem & Leaf & Pod & Bean & $\overline{\Delta_{\text {load }}}$ & Stem & Leaf & Pod & Bean & Stem & Leaf & Pod & $\overline{\text { Bean }}$ \\
\hline D8 & +0.42 & +0.90 & -0.25 & -1.07 & \pm 1.32 & +0.93 & -0.09 & +0.11 & -0.92 & \pm 1.03 & +27.8 & +70.9 & -21.7 & -44.9 & +24.0 & -3.2 & +3.5 & -18.2 \\
\hline D3 & +0.65 & -0.05 & +0.06 & -0.66 & \pm 0.71 & +2.59 & -0.09 & -1.08 & -1.42 & \pm 2.59 & +54.2 & -5.4 & +6.0 & -53.0 & +52.1 & -2.4 & -24.7 & -16.4 \\
\hline D2 & +1.92 & +0.38 & -0.58 & -1.73 & \pm 2.31 & +2.79 & -0.18 & -0.09 & -2.59 & \pm 2.83 & +49.9 & +26.2 & -36.7 & -58.0 & +40.4 & -3.6 & -1.6 & -22.9 \\
\hline D15 & +1.07 & +1.47 & -0.47 & -2.06 & \pm 2.54 & +0.23 & +1.75 & -1.36 & -0.63 & \pm 1.98 & $+44 . .9$ & +73.9 & $-24.7-$ & -47.8 & +4.4 & +22.0 & -32.4 & -6.9 \\
\hline D14 & +1.02 & +0.86 & -0.35 & -1.52 & \pm 1.88 & +4.60 & -0.63 & -1.19 & -2.77 & \pm 4.60 & +57.0 & +72.9 & -25.2 & -56.1 & +56.4 & -16.7 & -20.6 & -23.0 \\
\hline D11 & +1.11 & +0.35 & -0.34 & -1.12 & \pm 1.46 & -1.11 & +1.58 & -0.23 & -0.21 & \pm 1.57 & +91.7 & +43.2 & -38.2 & -60.2 & -20.8 & +38.8 & -5.2 & -2.1 \\
\hline D4 & +0.75 & +0.92 & -0.70 & -0.97 & \pm 1.67 & +0.33 & -0.27 & -0.23 & +0.17 & \pm 0.50 & +41.7 & +68.7 & -49.3 & -35.4 & +5.4 & -6.5 & -4.9 & +1.8 \\
\hline D12 & +2.35 & +4.72 & -2.25 & -4.82 & \pm 7.07 & +3.26 & +0.23 & -1.53 & -2.00 & \pm 3.51 & +62.7 & +153.7 & -78.9 & -82.4 & +36.5 & +3.2 & -21.8 & -13.6 \\
\hline D9 & +1.19 & +0.43 & -0.44 & -1.17 & \pm 1.62 & -1.72 & +1.20 & -0.37 & +0.87 & \pm 2.08 & +70.8 & +33.6 & -31.9 & -41.6 & -22.6 & +20.2 & -6.5 & +6.7 \\
\hline D1 & +0.54 & +0.34 & -0.34 & -0.54 & \pm 0.88 & -0.92 & +0.53 & +0.26 & +0.13 & \pm 0.92 & +41.5 & +30.9 & -37.0 & - 30.0- & -16.6 & +10.5 & +7.2 & +2.4 \\
\hline D5 & -0.13 & +0.85 & -0.34 & -0.38 & \pm 0.85 & +0.41 & +2.15 & -0.58 & -2.14 & \pm 2.64 & -5.8 & +53.5 & -19.2 & -13.0 & +3.5 & +27.3 & -6.1 & -11.5 \\
\hline D10 & +0.76 & +1.05 & -0.49 & -1.33 & \pm 1.82 & -0.91 & +1.61 & -2.67 & +1.91 & \pm 3.55 & +46.9 & +98.1 & -43.0 & -56.1 & -6.9 & +19.1 & -20.7 & +9.8 \\
\hline D6 & +0.63 & +0.89 & -0.71 & -0.81 & \pm 1.52 & -3.92 & +2.67 & -0.36 & +1.67 & \pm 4.31 & +29.6 & +62.7 & -45.8 & -24.8 & -23.0 & +26.0 & -3.4 & +6.6 \\
\hline D7 & +0.26 & +1.48 & -0.62 & -1.12 & \pm 1.74 & -2.91 & +4.36 & -3.76 & +2.39 & \pm 6.71 & +14.0 & +100.0 & -40.5 & -61.4 & -15.9 & +30.4 & -24.8 & +8.2 \\
\hline D13 & +0.77 & +0.29 & -0.17 & -0.89 & \pm 1.06 & +0.33 & +1.75 & -1.37 & -0.63 & \pm 3.63 & +57.5 & +19.7 & -12.6 & -32.0 & +1.5 & +8.70 & -16.4 & -1.6 \\
\hline
\end{tabular}

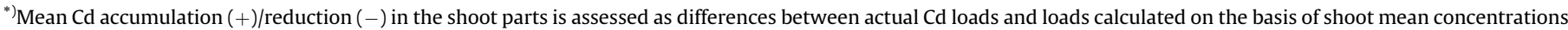
in the studied cultivars.

markers of possible Cd-excluding properties of soybean cultivars were Cd concentrations in shoot and enrichment factors EF. Due to the overall similarity of Cd concentrations in seed and shoot at elevated Cd concentrations in soil, evaluation of Cd concentration in shoot before bean formation by using e.g. Sugiyama et al. (2011) method should give a preliminary estimation of $\mathrm{Cd}$ content in seeds for the selection of soybean cultivars for safe food/feed production in the target cropland with elevated $\mathrm{Cd}$ concentrations. This study demonstrates that soybean cultivars show strongly differentiated, individual threshold levels of excessive Cd uptake from soils and accumulation it in seeds in concentrations exceeding food and feed safety standards already at moderate soil pollution with Cd. Under the circumstances, there are two options for cultivation of safe soybean products: (1) searching for low Cd-accumulating genotypes by testing $\mathrm{Cd}$ concentration in shoot of plants grown in soils of the target elevated pollution level; (2) performing comparative studies for selecting cultivars - the lowest Cd-accumulators for a broad range of $\mathrm{Cd}$ concentrations in soil and evaluating maximum Cd concentration in soil for each individual cultivar that assures soybean food safety for cultivating it in soils within the assessed safety limit. 


\section{Conclusions}

The results show that soybean cultivars have high $\mathrm{Cd}$ accumulation properties, which are predominantly determined by the flux rate through xylem and not related directly to $\mathrm{Cd}$ toxicity to plants exteriorized in the reduced yield. None of 15 studied cultivars could be qualified as cadmium excluders that could have been applied even to moderately polluted soil including Tiefeng 31 previously defined as such, while 6 cultivars fulfilled more tolerant requirements for feed purposes. Moreover, there was no uniform relation pattern between $\mathrm{Cd}$ concentration in soil and its uptake by root system, translocation to the above-ground parts, load redistribution among plant tissues and enrichment in beans not only of different, but of the same cultivars. This was not considered before at all and was possible to observe in this study due to the development and application of the novel Cd concentration/load trend analysis, Seed Accumulation Factors $S_{A F}$ as indicators of seed protection level and Cd load balance in different parts of plants grown in moderately polluted and unpolluted soils. At Cd uptake by soybean cultivars from unpolluted soil, free undisturbed Cd uptake by root system, translocation to shoot and substantial redistribution between its tissues occurred. In Cd accumulation in seeds (beans), besides genetically determined detoxification factors, important role played protective role of $\mathrm{Cd}$ accumulation in different parts of shoot (stem and leaves) that resulted in Cd load reduction in bean by $25-82 \%$ with respect to mean values in shoot at $\mathrm{SAF}_{\mathrm{n}}<0.5$. In the same cultivars grown in the moderately polluted soil, the most essential for $\mathrm{Cd}$ accumulation in seed was a plant genotype controlling $\mathrm{Cd}$ translocation through flux rate from soil via root to shoot, while seed detoxification mechanism and plant ability to protect seeds by accumulating $\mathrm{Cd}$ in other plant tissues played subordinate and declining role, or did not occur at all $\left(\mathrm{SAF}_{\mathrm{n}}\right.$. ranged from $>0.5$ to $>1.0$, whereas $C d$ load in bean was at the level from $-23 \%$ to $+11 \%$ related to mean values in shoot). Moderate pollution of soil with $\mathrm{Cd}$ caused also predominantly moderate reduction of biomass yield, mostly at the similar level and at the same share of different plant tissue parts in the total yield. This resulted in the similar pattern of concentration and load trends of the tested cultivars, however at the different quantitative relations for roots and shoots, displaying minor role of roots in Cd accumulation. The observed strong differentiation of seed protection mechanisms and their efficiency in soybean cultivars leads to the conclusion that searching for soybean genotypes assuring sustainable food safety will require individual approach to every soybean cultivar/soil system, while the key issue is selecting plants with adequate $\mathrm{EF}$ at the defined actual Cd concentrations in soil. However, only 15 soybean cultivars were tested in this manuscript, which is the limitation. Thus, more soybean cultivars to be determined at the same time in the future works may confirm these conclusion better. The important elements of cleaner production may lie in combined with clean soil and very low accumulation of heavy meal in soybean cultivars. Furthermore, based on the important findings of this experiment, further research may be more meaningful in the breeding of soybean cultivars with low accumulation of heavy metals.

\section{Acknowledgements}

This work was supported by the Special Plan in the Major Research \& Development of the 13th Five-Year Plan of China (2016YFD0800802), the National Natural Science Foundation of China $(41571300,31870488,31270540$ and 31070455$)$, and SinoMacedonia Government Scientific \& Technology Cooperation Project (3-2). The contribution of IEE-PAS (Poland) was performed within its statute activity, project No. 90/2017.

\section{References}

Araji, H.A., Wayayoka, A., Bavani, A.M., Amiri, E., Abdullah, A.F., Daneshian, J., Teh, C.B.S., 2018. Impacts of climate change on soybean production under different treatments of field experiments considering the uncertainty of general circulation models. Agric. Water Manag. 205, 63-71. https://doi.org/10.1016/j. agwat.2018.04.023.

Arao, T., Ae, N., Sugiyama, M., Takahashi, M., 2003. Genotypic differences in cadmium uptake and distribution in soybeans. Plant Soil 251 (2), 247-253.

Benitez, E.R., Hajika, M., Yamada, T., Takahashi, K., Oki, N., Yamada, N., Nakamura, T., Kanamaru, K., 2010. A major QTL controlling seed cadmium accumulation in soybean. Crop Sci. Abstr.- Crop Breed. Genet. 50 (5), 1728-1734. https://doi.org/ 10.2135/cropsci2009.11.0664.

Borgenproject, 2014. Soybeans and Global Food Security. https://borgenproject.org/ soybeans-global-food-security/. (Accessed 15 December 2017).

CECSPC - Chief Editor Chamber of Standard Press of China, 2009. Compilation of Standards for Feed Industry. Standard Press in China, Beijing (in Chinese).

Cheng, S., 2003. Heavy metal pollution in China: origin, pattern and control. Environ. Sci. Pollut. Res. Int. 10,192-198. https://doi.org/10.1065/espr2002.11.141.1.

Clemens, S., 2006. Toxic metal accumulation, responses to exposure and mechanisms of tolerance in plants. Biochimie (Paris) 88, 1707-1719. https://doi.org/ 10.1016/j.biochi.2006.07.003.

CRLTAP - Convention on Long- Range Transboundary Air Pollution, 1983. http:// www.unece.org/env/lrtap/welcome.html. (Accessed 5 July 2018).

Codex Alimentarius Commission, March 2001. Joint FAO/WHO Food Standards Programme. Comments Submitted on the Draft Guideline Level and Proposed Draft Maximum Levels for Cadmium, Codex Committee on Food Additives and Contaminants. Thirty-third Session, CX/FAC 01/28. The Hague, The Netherlands, pp. 12-16. www.fao.org/tempref/codex/Meetings/CCFAC/CCFAC34/fao2_24e. pdf.

Corguinha, A.P.B., de Souza, G.A., Gonçalves, V.C., de Andrade Carvalho, C., de Lima, W.E.A. Martins, F.A.D. Yamanaka, C.H., Francisco, E.A.B., Guilherme, L.R.G., 2015. Assessing arsenic, cadmium, and lead contents in major crops in Brazil for food safety purposes. J. Food Compos. Anal. 37, 143-150. https://doi.org/10. 1016/jfca.2014.08.004.

EMEP, 1984. Cooperative Programme for Monitoring and Evaluation of the Longrange Transmission of Air Pollutants in Europe. http://www.emep.int/index. html. (Accessed 5 February 2018).

EMEP Status Report 2, 2017. Assessment of Heavy Metal Transboundary Pollution on Regional and National Scales, Transition to the New EMEP Grid. MCS-E, CCC. http://www.msceast.org. (Accessed 10 March 2018).

FAO - Protein sources for the animal feed industry. www.fao.org/docrep/007/ y5019e03.htm (assessed 10 April, 2018).

Global Soybean Production, 2017. http://www.globalsoybeanproduction.com/. (Accessed 14 May 2018)

He, S., He, Z., Yang, X., Stofella, P.J., Baligar, V.C., 2015. Soil biogeochemistry, plant physiology, and phytoremediation of cadmium-contaminated soil. In: Sparks, D. (Ed.), Advances in Agronomy 134. Elsevier, Amsterdam, pp. 135-225.

Ishikawa, S., Ae, N., Sugiyama, M., Murakami, M., Arao, T., 2005. Genotypic variation in shoot cadmium concentration in rice and soybean in soils with different level of cadmium contamination. Soil Sci. Plant Nutr. 51, 101-108. https://doi.org/10. 1111/j.1747-0765.2005.tb00012.x.

Jegadeesan, S., Yu, R.Y, Yu, K, 2016. Genetic control of cadmium concentration in soybean seeds. In: Goyal, A.K. (Ed.), Grain Legumes. INTECH Open Science, pp. 79-102. http://www.intechopen.com/books/grain-legumes.

Jones Jr., J.B., 2001. In: Laboratory Guide for Conducting Soil Tests and Plant Analysis, first ed. CRC Press, Taylor \& Francis Group, Boca Raton.

Kabata-Pendias, A., 2011. In: Trace Elements in Soils and Plants, fourth ed. CRC Press. Taylor \&Francis Group, Boca Raton.

Kobori, G., Okazaki, M., Motobayashi, T., Matsukawa, K., 2011. Differences of cadmium uptake and accumulation among soybean (Glycine max) cultivars. In: Gilkes, R., Prakongkep, N. (Eds.), 19th World Congress of Soil Science 2010, 1-6 August 2010. Australian Society of Soil Science Inc., Curran Assoc. Inc., Proceedings.com., Red Hook, NY, USA, Brisbane, Australia, pp. 3228-3231.

Liu, W.T., Zhou, Q.X., An, J., Sun, Y.B., Liu, R., 2010. Variations in cadmium accumulation among Chinese cabbage cultivars and screening for Cd-safe cultivars. J. Hazard Mater. 173, 737-743, https://doi.org/10.1016/j.jhazmat.2009.08.147.

Liu, Z., Zhang, Q., Han, T., Ding, Y., Sun, J., Wang, F., Zhu, C., 2016. Heavy metal pollution in a soil-rice system in the Yangtze River region of China. Int. J. Environ. Res. Publ. Health 13 (1),63. https://doi.org/10.3990/ijerph13010063.

Lu, R.K., 1999. Analytical Methods of Agricultural Chemistry in Soil. China Agricultural S \& T Press, Beijing, China.

MEP, 2007. Environmental Quality Standard for Soils (GB 15618-1995. Putting into Effect as of Mar. 1, 1996). MEP, Beijing. http://english.mep.gov.cn/standards/Soil/ Quality_Standard3/200710/t20071024_111882.htm. (Accessed 15 November 2017).

MHC - Ministry of Health of the People's Repubic of China, 2013. National Food Safety Standard of Maximum Levels of Contaminants in Foods. Standard Press of China, Beijing (in Chinese).

Orisakwe, O.E., Nduka, J.K., Amadi, C.N., Dike, D.O., Bede, O., 2012. Heavy metals health risk assessment for population via consumption of food crops and fruits in Owerri, South Eastern Nigeria. Chem. Cent. J. 6, 77-83. https://doi.org/10. 1186/1752-153X-6-77.

Page, A.L., Chang, A.C., El-Amamy, M., 1987. Cadmium level in soils and crops in the 
United States. In: Hutchinson, T.C., Meema, K.M. (Eds.), Lead, Mercury, Cadmium and Arsenic in the Environment. SCOPE. J. Wiley \& Sons Ltd., pp. 119-146

Philis, G., Gracey, E.O., Gansel, L.C., Fet, A.M., Rebours, C., 2018. Comparing the primary energy and phosphorus consumption of soybean and seaweed-based aquafeed proteins A material and substance flow analysis. J. Clean. Prod. 200, 1142-1153. https://doi.org/10.1016/j.jclepro.2018.07.247.

Raza, G., Ahmad, N., Hussain, M., Zafar, Y., Rahman, M., 2016. Role of genetics and genomics in mitigating abiotic stresses in soybeans. In: Miransari, M. (Ed.), Environmental Stresses in Soybean Production. Soybean Production, 2. Elsevier Inc., Academic Press, pp. 205-228.

Salazar, M.J., Rodriguez, J.H., Leonardo Nieto, G., Pignata, M.L., 2012. Effects of heavy metal concentrations $(\mathrm{Cd}, \mathrm{Zn}$ and $\mathrm{Pb})$ in agricultural soils near different emission sources on quality, accumulation and food safety in soybean [Glycine max (L.) Merrill]. J. Hazard Mater. 233-234, 244-253. https://doi.org/10.1016/j. jhazmat.2012.07.026.

STATISTA - The Statistics Portal, 2018. Leading Soybean Producing Countries Worldwide from 2012/13 to 2017/18 (in million metric tons). https://www. statista.com/statistics/263926/soybean-production-in-selected-countriessince-1980/. (Accessed 10 January 2018).

Sugiyama, M., Ae, N., Arao, T., 2007. Role of roots in seed cadmium concentration among soybean cultivars - proof by grafting experiment. Plant Soil 295, 1-11. https://doi.org/10.1007/s11104-007-9252-2.

Sugiyama, M., 2009. Differences among soybean cultivars with regard to the cadmium-accumulation patterns in various organs. In: The Proceedings of the International Plant Nutrition Colloquium XVI UC Davis. EScholarship. University of California. http://escholatship.org/uc/item/71n1j212.

Sugiyama, M., Ae, N., Hajika, M., 2011. Developing of a simple method for screening soybean seedling cadmium accumulation to select soybean genotypes with low seed cadmium. Plant Soil 341, 413-422. https://doi.org/10.1007/s11104-010 0654-1.

Thoenes, P., 2005. Soybean International Commodity Profile. Background Paper for the Competitive Commercial Agriculture in Sub-saharan Africa (CAAA) Study siteresources. worldbank.org/INTAFRICA/Resources/254994-1215457178567 Soybean_Profile.pdf. (Accessed 10 April 2018).

Wang, W., Song, S., 2008. Main characteristics and cultivation techniques of a new high oil soybean variety Liaodou 21. Soybean Bull 2, 42-43.

Xu, Y.G., Yu, W.T., Ma, H., Zhou, H., 2015. Potential risk of cadmium in a soil-plant system as a result of long-term (10 years) pig manure application. Plant Soil Environ. 61 (8), 352-357. https://doi.org/10.17221/100/2015-PSE.

Zhan, J., Wei, S., Niu, R., Li, Y., Wang, S., Zhu, J., 2013. Identification of rice cultivar with exclusive characteristic to $\mathrm{Cd}$ using a field-polluted soil and its foreground application. Environ. Sci. Pollut. Res. 20 (4), 2645-2650. https://doi.org/ 10.1007/s11356-012-1185-5.

Zhao, Y., Fang, X., Mu, Y., Cheng, Y., Ma, Q., Nian, H., Yang, C., 2014. Metal pollution $(\mathrm{Cd}, \mathrm{Pb}, \mathrm{Zn}$, and $\mathrm{As})$ in agricultural soils and soybean, Glycine max, in Southern China. Bull. Environ. Contam. Toxicol. 92 (4), 427-432. https://doi.org/10.1007/ s00128-014-1218-5.

Zhi, Y., He, K., Sun, Y., Zhou, Q., 2015. Assessment of potential cadmium excluder cultivars at different concentrations of Cd in soils. J. Environ. Sci. 15, 108-114. https://doi.org/10.1016/j.jes.2015.01.031.

Zhou, Q., Liu, Z., Liu, Y., Jiang, J., Xu, R., 2016. Relative abundance of chemical forms of $\mathrm{Cu}(\mathrm{II})$ and $\mathrm{Cd}(\mathrm{II})$ on soybean roots as influenced by $\mathrm{pH}$, cations and organic acids. Sci. Rep. 6, 36373. https://doi.org/10.1038/srep3673.

Zhuang, P., Li, Z.-A., Zou, B., Xia, H.-P., Wang, G., 2013. Heavy metal contamination in soil and soybean near the Dabaoshan Mine, South China. Pedosphere 23 (3), 298-304. ISSN 1002-1060 CN 32-1315/P. 